\title{
THE SECOND ENCLOSURE MOVEMENT AND THE CONSTRUCTION OF THE PUBLIC DOMAIN
}

\author{
JAMES BOYLE* \\ The law locks up the man or woman \\ Who steals the goose from off the common \\ But leaves the greater villain loose \\ Who steals the common from off the goose. \\ The law demands that we atone \\ When we take things we do not own \\ But leaves the lords and ladies fine \\ Who take things that are yours and mine. \\ The poor and wretched don't escape \\ If they conspire the law to break; \\ This must be so but they endure \\ Those who conspire to make the law. \\ The law locks up the man or woman \\ Who steals the goose from off the common \\ And geese will still a common lack \\ Till they go and steal it back.
}

Anonymous

\section{PART ONE: ENCLOSURE}

I

\section{THE FIRST ENClOSURE MOVEMENT}

This poem ${ }^{1}$ is one of the pithiest condemnations of the English enclosure movement, the process of fencing off common land and turning it into private

Copyright (C) 2003 by James Boyle

This article is made available by the author under a Creative Commons License at http://creativecommons.org/licenses/by-sa/1.0. It is also available at http://www.law.duke.edu/journals/ 66LCPBoyle.

* Professor of Law, Duke University.

An earlier and considerably shorter version of this article appeared as Fencing off Ideas, DAEDALUS, Spring 2002, at 13. I wish to thank Yochai Benkler and Larry Lessig for comments, and Matt Jones, Greg Manter, and Victoria Von Portatius for their research.

1. Apart from being anonymous, the poem is extremely hard to date. It probably comes from the enclosure controversies of the eighteenth century. However, the earliest reference to it that I have been able to discover is from 1821. Edward Birch was moved to compose some (fairly poor) verses in response when he reported "seeing the following jeu d'esprit in a Handbill posted up in Plaistow, as a 'CAUTION' to prevent persons from supporting the intended inclosure of Hainault or Waltham Forest." He then quotes a version of the poem. Edward Birch, TICKLER MAG., Feb. 1821, at 45. In 1860, 
property. ${ }^{2}$ In a few lines, the poem manages to criticize double standards, expose the artificial and controversial nature of property rights, and take a slap at the legitimacy of state power. And it does this all with humor, without jargon, and in rhyming couplets. Academics (including this one) should take note. Like most of the criticisms of the enclosure movement, the poem depicts a world of rapacious, state-aided "privatization," a conversion into private property of something that had formerly been common property or, perhaps, had been outside of the property system altogether. Sir Thomas More went further, though he used sheep rather than geese to make his point. He argued that enclosure was not merely unjust in itself, but harmful in its consequences-a cause of economic inequality, crime, and social dislocation:

But yet this is not only the necessary cause of stealing. There is another, which, as I suppose, is proper and peculiar to you Englishmen alone. What is that, quoth the Cardinal? Forsooth my lord (quoth I) your sheep that were wont to be so meek and tame, and so small eaters, now, as I hear say, be become so great devourers and so wild, that they eat up, and swallow down the very men themselves. They consume, destroy, and devour whole fields, houses, and cities. For look in what parts of the realm doth grow the finest and therefore dearest wool, there noblemen and gentlemen ... leave no ground for tillage, they enclose all into pastures; they throw down houses; they pluck down towns, and leave nothing standing, but only the church to be made a sheep-house.... Therefore that one covetous and insatiable cormorant and very plague of his native country may compass about and enclose many thousand acres of ground together within one pale or hedge, the husbandmen be thrust out of their own.

The enclosure movement continues to draw our attention. It offers irresistible ironies about the two-edged sword of "respect for property," and lessons about the way in which the state defines and enforces property rights to pro-

a staff writer for the journal Notes and Queries declares that "the animosity excited against the Inclosure Acts and their authors ... was almost without precedent: though fifty years and more have passed, the subject is still a sore one in many parishes... I remember some years ago, in hunting over an old library discovering a box full of printed squibs, satires and ballads of the time against the acts and those who were supposed to favour them,- - the library having belonged to a gentleman who played an active part on the opposition side." The author then quotes the first verse as a "naive epigram ... which forcibly impressed itself on my memory." "Exon" Ballads Against Inclosures, 9 NOTES AND QUERIES, at 130-131 (2nd ser., Feb. 1860). The context makes it appear that the poem itself must date from the late 18th century. In other sources, the poem is sometimes dated at 1764 and said to be in response to Sir Charles Pratt's fencing of common land. See, e.g., Dana A. Freiburger, John Thompson, English Philomath-A Question of Land Surveying and Astronomy, poster paper submitted to the History of Astronomy Workshop University of Notre Dame, (July 1-4, 1999), note 15, available at http://www.nd.edu/ histast4/exhibits/papers/Freiburger/index.html (last visited Dec. 19, 2002). This attribution is widespread and may well be true, but I have been able to discover no contemporary source material that sustains it. By the end of the nineteenth century, the poem was being quoted, sometimes with amusement and sometimes with agreement, on both sides of the Atlantic. See Ezra S. Carr, Aids and Obstacles to Agriculture on the Pacific-Coast, in THE PATRONS OF HusBandRY ON THE PACIFIC COAST 290, 291 (San Francisco, A.L. Bancroft and Co. 1875); EdWARD P. CHEYNEY, AN INTRODUCTION TO THE INDUSTRIAL AND SOCIAL HISTORY OF ENGLAND 219 (1901).

2. Although we refer to it as "the enclosure movement," it was actually a series of enclosures that started in the fifteenth century and went on, with differing means, ends, and varieties of state involvement, until the nineteenth century. See, e.g., J.A. Yelling, COMmON FIELD AND EnClosure IN ENGLAND, 1450-1850 (1977).

3. Thomas More, Utopia 32 (Alfred A. Knopf 1992) (1947). 
mote controversial social goals. The most strident critics of the enclosure movement argue that it imposed devastating costs on one segment of society.

\begin{abstract}
Enclosures have appropriately been called a revolution of the rich against the poor. The lords and nobles were upsetting the social order, breaking down ancient law and custom, sometimes by means of violence, often by pressure and intimidation. They were literally robbing the poor of their share in the common, tearing down the houses which, by the hitherto unbreakable force of custom, the poor had long regarded as theirs and their heirs'. The fabric of society was being disrupted. Desolate villages and the ruins of human dwellings testified to the fierceness with which the revolution raged, endangering the defences of the country, wasting its towns, decimating its population, turning its overburdened soil into dust, harassing its people and turning them from decent husbandmen into a mob of beggars and thieves. Though this happened only in patches, the black spots threatened to melt into a uniform catastrophe.
\end{abstract}

Some of these costs were brutally and relentlessly "material"-for example, the conversion of crofters and freeholders into debt-peons, seasonal wage-laborers, or simply, as More argued in Utopia, and Polanyi argues 400 years later, into beggars and thieves. ${ }^{5}$ But other harms are harder to classify: the loss of a form of life; the relentless power of market logic to migrate to new areas, disrupting traditional social relationships and perhaps even views of the self or the relationship of human beings to the environment.

So much for the bad side of the enclosure movement. For many economic historians, everything I have said up to now is the worst kind of sentimental bunk, romanticizing a form of life that was neither comfortable nor noble, and certainly not very egalitarian. The big point about the enclosure movement is that it worked; this innovation in property systems allowed an unparalleled expansion of productive possibilities. ${ }^{6}$ By transferring inefficiently managed common land into the hands of a single owner, enclosure escaped the aptly named "tragedy of the commons." It gave incentives for large-scale investment, allowed control over exploitation, and, in general, ensured that resources could be put to their most efficient use. Before the enclosure movement, the feudal lord would not invest in drainage systems, sheep purchases, or crop rotation that might increase yields from the common-he knew all too well that the fruits of his labor could be appropriated by others. The strong private property rights and single entity control that were introduced in the enclosure movement avoid the tragedies of overuse and underinvestment: ${ }^{7}$ More grain will be grown, more sheep raised; consumers will benefit; and fewer people will starve in the long run. If the price of this social gain is a greater concentration of economic power, or the introduction of market forces into areas where they previously had not been so obvious, or the disruption of a modus vivendi with the envi-

4. Karl Polanyi, The Great Transformation: The Political and Economic Origins OF OUR TIME 35 (1957); see also E.P. THOMPSON, THE MAKING OF THE ENGLISH WORKING Class 218 (1963).

5. POLANYI, supra note 4 at 35 .

6. See generally LORD ERNLE, ENGLish FARMing PAST AND PRESENT (1961).

7. For an excellent summary of the views of Hobbes, Locke and Blackstone on these points, see Hannibal Travis, Pirates of the Information Infrastructure: Blackstonian Copyright and the First Amendment, 15 BERKELEY TECH. L.J. 777, 789-803 (2000). 
ronment-then, enclosure's defenders say, so be it. In their view, the agricultural surplus produced by enclosure helped to save a society devastated by the mass deaths of the sixteenth century. Those who weep tears about the terrible effects of private property should realize that it literally saves lives.

I am not going to concentrate on the first enclosure movement here. It is worth noting, however, that while earlier scholarship extolled enclosure's beneficial effects, ${ }^{8}$ some more recent empirical work has indicated that it had few, if any, effects in increasing agricultural production. ${ }^{9}$ The tragedies predicted in articles such as Hardin's Tragedy of the Commons did not occur..$^{10}$ In fact, the commons frequently may have been well-run, though the restraints on its depletion and the incentives for investment in it may have been "softer" than the hard-edged norms of private property. ${ }^{11}$ Thus, while enclosure produced significant distributional changes of the kind that so incensed an earlier generation of critical historians, there are significant questions about whether it led to greater efficiency or innovation. These results are little known, however, outside of the world of economic historians. "Everyone" knows that a commons is by definition tragic, and that the logic of enclosure is as true today as it was in the fifteenth century. Private property saves lives.

8. See ERNLE, supra note 6.

9. The most notable work is that of Robert Allen. See Robert C. Allen, The Efficiency and Distributional Consequences of Eighteenth Century Enclosures, 92 ECON. J. 937 (1982) [hereinafter Allen, Efficiency]; Robert C. Allen, EnClosure AND THE YEOMAN (1994). Allen argues that the enclosure movement produced major distributional consequences, but little observable efficiency gain. The pie was carved up differently, to the advantage of the landlords, but made no larger. In contrast, Michael Turner sees enclosure as one possible, though not necessary, route to productivity gains. See Michael Turner, English Open Fields and Enclosures: Retardation or Productivity Improvements, $46 \mathrm{~J}$. ECON. HIST. 669, 688 (1986). Donald McCloskey's work also argues for efficiency gains from enclosure, largely from the evidence provided by rent increases. See Donald N. McCloskey, The Enclosure of Open Fields: Preface to a Study of Its Impact on the Efficiency of English Agriculture in the Eighteenth Century, 32 J. ECON. HIST. 15 (1972); Donald N. McCloskey, The Prudent Peasant: New Findings on Open Fields, 51 J. ECON. HIST. 343 (1991). In Allen's view, however, the change in rents was largely a measure of the way that changes in legal rights affected the bargaining power of the parties and the cultural context of rent negotiations; enclosure allowed landlords to capture more of the existing surplus produced by the land, rather than dramatically expanding it. "[T]he enclosure movement itself might be regarded as the first state sponsored land reform. Like so many since, it was justified with efficiency arguments, while its main effect (according to the data analyzed here) was to redistribute income to already rich landowners." Allen, Efficiency, supra at 950-51. Those contemporary accounts which argue that enclosure led to productivity gains tend to be more qualified in their praise. Compare Turner, supra, ("Enclosure cannot be seen as the automatic open door to this cycle of agricultural improvement, but the foregoing estimates do suggest that perhaps it was a door which opened frequently, and with profit.") with the more positive account given in ERNLE, supra note 6.

10. Garrett Hardin, The Tragedy of the Commons, SCIENCE, Dec. 13, 1968, at 1243.

11. The possibility of producing "order without law" and, thus, sometimes governing the commons without tragedy, has also fascinated scholars of contemporary land use. See ROBERT C. ElLICKSON, ORDER Without LAW: HOW NeIGHBORS SETTLE DisPuTES (1991); ElinOR OSTROM, GOVERNING THE COMMONS: THE Evolution OF INSTITUTIONS FOR COLLECTIVE ACTION (1991). 


\section{II}

\section{THE SECOND ENCLOSURE MOVEMENT}

This is all very well, but what does it have to do with intellectual property? We are in the middle of a second enclosure movement. It sounds grandiloquent to call it "the enclosure of the intangible commons of the mind," but in a very real sense that is just what it is. ${ }^{12}$ True, the new state-created property rights may be "intellectual" rather than "real," but once again things that were formerly thought of as either common property or uncommodifiable are being covered with new, or newly extended, property rights.

Take the human genome as an example. Again, the supporters of enclosure have argued that the state was right to step in and extend the reach of property rights; that only in this way could we guarantee the kind of investment of time, ingenuity, and capital necessary to produce new drugs and gene therapies. ${ }^{13}$ To the question, "Should there be patents over human genes?," the supporters of enclosure would answer that private property saves lives. ${ }^{14}$ The opponents of enclosure have claimed that the human genome belongs to everyone, that it literally the common heritage of humankind, that it should not and perhaps in some sense cannot be owned, and that the consequences of turning over the human genome to private property rights will be dreadful, as market logic invades areas which should be the farthest from the market. In stories about stem cell and gene sequence patents, critics have mused darkly about the way in which the state is handing over monopoly power to a few individuals and corporations, potentially introducing bottlenecks and coordination costs that slow down innovation. ${ }^{15}$

Alongside these accounts of the beneficiaries of the new property scheme run news stories about those who were not so fortunate, the commoners of the genetic enclosure. Law students across America read Moore v. Regents of University of California, a California Supreme Court case deciding that Mr. Moore had no property interest in the cells derived from his spleen. ${ }^{16}$ The court tells us that giving private property rights to "sources" would slow the free-wheeling

12. The analogy to the enclosure movement has been too succulent to resist. To my knowledge, Ben Kaplan, Pamela Samuelson, Yochai Benkler, David Lange, Chrisopher May, David Bollier and Keith Aoki have all employed the trope, as I myself have on previous occasions. For a particularly thoughtful and careful development of the parallel between the two enclosure movements, see generally Travis, supra note 7.

13. See, e.g., William A. Haseltine, The Case for Gene Patents, TECH. REV., Sept./Oct. 2000, available at http://www.technologyreview.com/articles/haseltine0900.asp (last visited Dec. 19, 2002); $c f$. Alexander K. Haas, The Wellcome Trust's Disclosures of Gene Sequence Data into the Public Domain \& the Potential for Proprietary Rights in the Human Genome, 16 BERKELEY TECH. L.J. 145 (2001).

14. See, e.g., Haseltine, supra note 13; Press Release, Biotechnology Industry Association, Genentech, Incyte Genomics Tell House Subcommittee Gene Patents Essential For Medical Progress (July 13, 2000), available at http://www.bio.org/genomics/genetech.html.

15. See, e.g., Howard Markel, Patents Could Block the Way to a Cure, N.Y. TIMES, Aug. 24, 2001, at A19. For the general background to these arguments, see Rebecca S. Eisenberg, Patenting the Human Genome, 39 EMORY L.J. 721, 740-44 (1990).

16. 793 P.2d 479, 488-97 (Cal. 1990). 
practice researchers have of sharing their cell lines with all and sundry. ${ }^{17}$ The doctors whose inventive genius created a billion-dollar cell line from Mr. Moore's "naturally occurring raw material," by contrast, are granted a patent. Private property rights here, by contrast, are a necessary incentive to research. ${ }^{18}$ Economists on both sides of the enclosure debate concentrate on the efficient allocation of rights. Popular discussion, on the other hand, doubtless demonstrating a reprehensible lack of rigor, returns again and again to more naturalistic assumptions such as the "commonness" of the property involved or the idea that one owns one's own body. ${ }^{19}$

The genome is not the only area to be partially "enclosed" during this second enclosure movement. The expansion of intellectual property rights has been remarkable-from business method patents ${ }^{20}$ to the Digital Millennium Copyright Act, ${ }^{21}$ to trademark antidilution rulings, ${ }^{22}$ to the European Database Protection Directive. ${ }^{23}$ The old limits to intellectual property rights-the antierosion walls around the public domain-are also under attack. The annual process of updating my syllabus for a basic Intellectual Property course provides a nice snapshot of what is going on. I can wax nostalgic looking back to a five-year-old text, with its confident list of subject matter that intellectual property rights couldn't cover, the privileges that circumscribed the rights that did exist, and the length of time before a work falls into the public domain. In each case, the limits have been eaten away.

To be sure, there is a danger of overstatement. The very fact that the changes have been so one-sided makes it hard to resist exaggerating their impact. In 1918, Brandeis confidently claimed that " $[\mathrm{t}]$ he general rule of law is,

17. Id. at 493-94. One imagines Styrofoam coolers criss-crossing the country by FedEx in an orgy of communistic flesh swapping.

18. Id. at 493 .

19. I might be suspected of anti-economist irony here. In truth, neither side's arguments are fully satisfying. It is easy to agree with Richard Posner that the language of economics offers a "thin and unsatisfactory epistemology" through which to understand the world. RICHARD POSNER, THE PROBLEMS OF JURISPRUDENCE xiv (1990) (citing the words of Paul Bator). On the other hand, explaining what it means to "own one's own body," or specifying the non-commodifiable limits on the market turns out to be a remarkably tricky business, as Margaret Jane Radin has shown with great elegance. See MARGARET JANE RADIN, CONTESTED COMMODITIES (1996).

20. See State St. Bank \& Trust Co. v. Signature Fin. Group, 149 F.3d 1368, 1373 (D.C. Cir. 1998)

21. Pub. L. No. 105-304, 112 Stat. 2860 (1998) (codified as amended in scattered sections of 5, 17, 28 and 35 U.S.C.).

22. See, e.g., Mead Data Central, Inc. v. Toyota Motor Sales, U.S.A., Inc., 875 F.2d 1026, 1030 (2d Cir. 1989); Mutual of Omaha Insurance Co. v. Novak, 836 F. 2 d 397 (8th Cir. 1987), cert. denied 109 S. Ct. 326 (1987); American Express Co. v. Vibra Approved Laboratories Corp., 10 U.S.P.Q. 2d (BNA) 2006 (S.D.N.Y. Apr. 17, 1989); Jordache Enters., Inc. v. Hogg Wyld, Ltd., 625 F. Supp. 48, 56 (D.N.M. 1985), aff'd, 828 F.2d 1482 (10th Cir. 1987); Pillsbury Co. v. Milky Way Prod., Inc., 215 U.S.P.Q. (BNA) 124 (N.D. Ga. Dec. 24, 1981); General Electric Co. v. Almpa Coal Co., 205 U.S.P.Q. (BNA) 1036 (D.Mass. Oct. 12, 1979); Reddy Communications, Inc. v. Environmental Action Found., Inc., 199 U.S.P.Q. (BNA) 630 (D.D.C. Nov. 11, 1977); Coca-Cola Co. v. Gemini Rising Inc., 346 F. Supp. 1183 (E.D.N.Y. 1972).

23. Directive 96/9/EC of the European Parliament and of the Council of 11 March 1996 on the Legal Protection of Databases, 1996 O.J. (L 77) 20, available at http://europa.eu.int/ISPO/infosoc/legreg/ docs/969ec.html [hereinafter Directive] (last visited Dec. 19, 2002). 
that the noblest of human productions-knowledge, truths ascertained, conceptions, and ideas-become, after voluntary communication to others, free as the air to common use." ${ }^{24}$ That baseline-intellectual property rights are the exception rather than the norm; ideas and facts must always remain in the public domain -is still supposed to be our starting point. ${ }^{25}$ It is, however, under attack. Both overtly and covertly, the commons of facts and ideas is being enclosed. Patents are increasingly stretched out to cover "ideas" that twenty years ago all scholars would have agreed were unpatentable. ${ }^{26}$ Most troubling of all are the attempts to introduce intellectual property rights over mere compilations of facts. $^{27}$ If Anglo-American intellectual property law had an article of faith it was that unoriginal compilations of facts would remain in the public domain, that this protection of the raw material of science and speech was as important to the next generation of innovation as the intellectual property rights themselves. ${ }^{28}$ The system would hand out monopolies in inventions and in original expression, while the facts below (and ideas above) would remain free for all to build upon. But this premise is being undermined. Some of the challenges are subtle: In patent law, stretched interpretations of novelty and non-obviousness allow intellectual property rights to move closer and closer to the underlying datalayer; gene sequence patents come very close to being rights over a particular discovered arrangement of data-Cs, Gs, As, and Ts. ${ }^{29}$ Other challenges are overt: The European Database Directive does (and the various proposed bills in the United States would) create proprietary rights over compilations of facts, often without even the carefully framed exceptions of the copyright scheme, such as the usefully protean category of fair use..$^{30}$

The older strategy of intellectual property law was a "braided" one: Thread a thin layer of intellectual property rights around a commons of material from which future creators would draw. Even that thin layer of intellectual property rights was limited to allow access to the material when the private property owner might charge too much. Fair use allows for parody, commentary and criticism, and also for "decompilation" of computer programs so that, for example, Microsoft's competitors can reverse engineer Word's features to make

24. Int'l News Serv. v. Associated Press, 248 U.S. 215, 250 (1918) (Brandeis, J., dissenting).

25. Yochai Benkler, Free as the Air to Common Use: First Amendment Constraints on Enclosure of the Public Domain, 74 N.Y.U. L. REV. 354, 361, 424 (1999) [hereinafter Benkler, Free as the Air].

26. The so-called "business method" patents, which cover such "inventions" as auctions or accounting methods, are an obvious example. See, e.g., State St. Bank \& Trust Co. v. Signature Fin. Group, Inc., 149 F.3d 1368, 1373 (Fed. Cir. 1998).

27. Collection of Information Antipiracy Act, S. 2291, 105th Cong. (1998); Database Investment and Intellectual Property Antipiracy Act of 1996, H.R. 3531, 104th Cong. (1996).

28. See, e.g., Feist Publ'ns v. Rural Tel. Serv. Co., 499 U.S. 340, 350, 354 (1991) (“Copyright treats facts and factual compilations in a wholly consistent manner. Facts, whether alone or as part of a compilation, are not original and therefore may not be copyrighted." To hold otherwise would "'distort[]" basic copyright principles in that it creates a monopoly in public domain materials without the necessary justification of protecting and encouraging the creation of 'writings' by 'authors."').

29. See Eisenberg, supra note 15; Haas, supra note 13.

30. See Directive, supra note 23. 
sure that their program can convert Word files. ${ }^{31}$ It may sound paradoxical, but in a very real sense protection of the commons was one of the fundamental goals of intellectual property law. In the new vision of intellectual property, however, property should be extended everywhere-more is better. Expanding patentable and copyrightable subject matter, lengthening the copyright term, giving legal protection to "digital barbed wire" even if it is used in part to protect against fair use: Each of these can be understood as a vote of no-confidence in the productive powers of the commons. We seem to be shifting from Brandeis's assumption that the "noblest of human productions are free as the air to common use" to the assumption that any commons is inefficient, if not tragic.

The expansion is more than a formal one. It used to be relatively hard to violate an intellectual property right. The technologies of reproduction or the activities necessary to infringe were largely, though not entirely, industrial. The person with the printing press who chooses to reproduce a book is a lot different from the person who lends the book to a friend or takes a chapter into class. The photocopier makes that distinction fuzzy, and the networked computer erases it altogether. In a networked society, copying is not only easy, it is a sine qua non of transmission, storage, caching, and, some would claim, even reading. ${ }^{32}$ As bioinformatics blurs the line between computer modeling and biological research, digital production techniques blur the line between listening, editing, and recreating. "Rip, mix, and burn," says the Apple advertisement. It marks a world in which the old regime of intellectual property, operating upstream as a form of industrial unfair competition policy, has been replaced. Intellectual property is now in and on the desktop and is implicated in routine creative, communicative, and just plain consumptive acts that each of us performs every day. The reach of the rights has been expanded at the same moment that their practical effect has been transformed.

III

\section{How Much of the InTANGible Commons Must We Enclose?}

So far I have argued that there are profound similarities between the first enclosure movement and the contemporary expansion of intellectual property, which I call the second enclosure movement. Once again, the critics and proponents of enclosure are locked in battle, hurling at each other incommensurable claims about innovation, efficiency, traditional values, the boundaries of the market, the saving of lives, the loss of familiar liberties. Once again, opposition to enclosure is portrayed as economically illiterate; the beneficiaries of enclo-

31. Those who prefer topographical metaphors might imagine a quilted pattern of public and private land, with legal rules specifying that certain areas, beaches for example, can never be privately owned, and with accompanying rules giving public rights of way through private land if there is a danger that access to the commons might otherwise be blocked.

32. See James Boyle, Shamans, Software, \& Spleens: Law and the Construction of THE INFORMATION SOCIETY 135 (1996) [hereinafter BOYLE, SHAMANS]; JESSICA LiTMAN, DigITAL COPYRIGHT 91 (2001). 
sure telling us that an expansion of property rights is needed in order to fuel progress. Indeed, the post-Cold War "Washington Consensus" is invoked to claim history teaches the only way one gets growth and efficiency is through markets; property rights, surely, are the sine que non of markets. ${ }^{33}$

But if there are similarities between our two enclosures, there are also profound dissimilarities; the networked commons of the mind has many different characteristics from the grassy commons of Old England. ${ }^{34}$ I want to concentrate here on two key differences between the intellectual commons and the commons of the first enclosure movement: differences that should lead us to question whether this commons is truly tragic and to ask whether stronger intellectual property rights really are the solution to our problems. These differences are well known; indeed, they are the starting point for most intellectual property law. Nevertheless, reflection on them might help to explain both the problems and the stakes in the current wave of expansion.

Unlike the earthy commons, the commons of the mind is generally "nonrival." Many uses of land are mutually exclusive. If I am using the field for grazing, it may interfere with your plans to use it for growing crops. By contrast, a gene sequence, an MP3 file, or an image may be used by multiple parties; my use does not interfere with yours. To simplify a complicated analysis, this means that the threat of overuse of fields and fisheries is generally not a problem with the informational or innovational commons. ${ }^{35}$ Thus, one type of tragedy of the commons is avoided. The concerns in the informational commons have to do with a different kind of collective action problem: the problem

33. The phrase "Washington Consensus" originated in John Williamson, What Washington Means by Policy Reform, in LATIN AmERICAN AdJuSTMENT: How Much Has HAPPENED? 7-38 (John Williamson ed., 1990). Over time, it has come to be used as shorthand for a neo-liberal view of economic policy that puts its faith in deregulation, privatization, and the creation and defense of secure property rights as the cure for all ills. See Joseph Stiglitz, The World Bank at the Millennium, 109 ECON. J. 577, 577-97 (1999). It has thus become linked to the triumphalist neo-liberal account of the end of history and the victory of unregulated markets. See Francis FukUyama, THE END OF History AND THE LAST MAN (1992). Neither of these two results are, to be fair, what its creator intended. See John Williamson, What Should The Bank Think About The Washington Consensus?, Institute for International Economics, available at http://www.iie.com/papers/williamson0799.htm (last visited Sept. 20, 2002).

34. The differences are particularly strong in the arguments over "desert:" Are these property rights deserved or are they simply violations of the public trust and privatizations of the commons? For example, some would say that we never had the same traditional claims over the genetic commons that the victims of the first enclosure movement had over their commons; this is more like newly discovered frontier land, or perhaps even privately drained marshland, than it is like well-known common land that all have traditionally used. In this case, the enclosers can claim (though their claims are disputed) that they discovered or perhaps simply made usable the territory they seek to own. The opponents of gene patenting, on the other hand, turn to religious and ethical arguments about the sanctity of life and the incompatibility of property with living systems even more frequently than the farmers of the eighteenth century. These arguments, and the appeals to free speech that dominate debates over digital intellectual property, have no precise analogue in debates over hunting or pasturage, although there are common themes. For example, we are already seeing nostalgic laments of the loss of the immemorial rights of Internet users. At the same time, the old language of property law is turned to this more evanescent subject matter; my favorite title is The Ancient Doctrine of Trespass to Web Sites. I. Trotter Hardy, The Ancient Doctrine of Trespass to Web Sites, 1996 J. ONLINE L. art. 7, available at http://www.wm.edu/law/publications/jol/95_96/hardy.html (last visited Dec. 19, 2002).

35. The exceptions to this statement turn out to be fascinating. In the interest of brevity, however, I will ignore them entirely. 
of incentives to create the resource in the first place. The difficulty comes because of the idea that information goods are not only non-rival (uses do not interfere with each other), they are also assumed to be non-excludable (it is impossible, or at least hard, to stop one unit of the good from satisfying an infinite number of users at zero marginal cost). Pirates will copy the song, the mousetrap, the drug formula. The rest of the argument is well known. Lacking an ability to exclude, creators will be unable to charge for their creations; there will be inadequate incentives to create. Thus, the law must step in and create a limited monopoly called an intellectual property right.

This is a well known argument, but it has recently acquired an historical dimension, a teleology of intellectual property maximalism. If the reason for intellectual property rights is the non-rival and non-excludable nature of the goods they protect, then surely the lowering of copying and transmission costs implies a corresponding need to increase the strength of intellectual property rights. Imagine a line. At one end sits a monk painstakingly transcribing Aristotle's Poetics. In the middle lies the Gutenberg printing press. Three-quarters of the way along the line is a photocopying machine. At the far end lies the Internet and the online version of the human genome. At each stage, copying costs are lowered and goods become both less rival and less excludable. My MP3 files are available to anyone in the world running Napster. Songs can be found and copied with ease. The symbolic end of rivalry comes when I am playing the song in Chapel Hill, North Carolina at the very moment that you are both downloading and listening to it in Kazakhstan-now that's non-rival. My point is that there seems to be an assumption that the strength of intellectual property rights must vary inversely with the cost of copying. To deal with the monk-copyist, we need no intellectual property right because physical control of the manuscript is enough. To deal with the Gutenberg press, we need the Statute of Anne. ${ }^{36}$ To deal with the Internet, we need the Digital Millennium Copyright Act, ${ }^{37}$ the No Electronic Theft Act, ${ }^{38}$ the Sonny Bono Term Extension Act, ${ }^{39}$ and perhaps even the Collections of Information Antipiracy Act. ${ }^{40}$ As copying costs approach zero asymptotically, intellectual property rights must approach perfect control. If a greater proportion of product value and gross national product is now in the form of value-added information, then we have still another reason to need strengthened protection. A five-dollar padlock would do for a garden shed, but not for a vault.

Like any attractive but misleading argument, this one has a lot of truth. The Internet does lower the cost of copying and, thus, the cost of illicit copying. Of

36. 13 Ann., c. 15 (Eng.).

37. Pub. L. No. 105-304, 112 Stat. 2860 (1998) (codified as amended in scattered sections of 5, 17, 28, and 35 U.S.C.).

38. Pub. L. No. 105-147, 111 Stat. 2678 (1997) (codified as amended in scattered sections of 17 and 18 U.S.C.).

39. Pub. L. No. 105-298, 112 Stat. 2827 (1998) (codified as amended in scattered sections of 17 U.S.C.)

40. S. 2291, 105th Cong. (1998). 
course, it also lowers the costs of production, distribution, and advertising, and dramatically increases the size of the potential market. Is the net result, then, a loss to rights-holders such that we need to increase protection to maintain a constant level of incentives? A large, leaky market may actually provide more revenue than a small one over which one's control is much stronger. What's more, the same technologies that allow for cheap copying also allow for swift and encyclopedic search engines - the best devices ever invented for detecting illicit copying. It would be impossible to say, on the basis of the evidence we have, that owners of protected content are better or worse off as a result of the Internet. $^{41}$ Thus, the idea that we must inevitably strengthen rights as copying costs decline doesn't hold water. And given the known static and dynamic costs of monopolies, and the constitutional injunction to encourage the progress of science and the useful arts, ${ }^{42}$ the burden of proof should be on those requesting new rights to prove their necessity.

How about the argument that the increasing importance of informationvalue-added and information-intensive products to the world economy means that protection must increase? Must the information commons be enclosed because it is now a more important sector of economic activity? ${ }^{43}$ This was certainly one of the arguments for the first enclosure movement. For example, during the Napoleonic War, enclosure was defended as a necessary method of increasing the efficiency of agricultural production, now a vital sector of a wartime economy. Here, we come to another big difference between the commons of the mind and the earthy commons. As has frequently been pointed out, information products are often made up of fragments of other information products; your information output is someone else's information input. ${ }^{44}$ These inputs may be snippets of code, discoveries, prior research, images, genres of work, cultural references, or databases of single nucleotide polymorphismseach is raw material for future innovation. Every potential increase of protection, however, also raises the cost of, or reduces access to, the raw material from which you might have built those products. The balance is a delicate one; one Nobel Prize-winning economist has claimed that it is actually impossible to strike that balance so as to produce an informationally efficient market. ${ }^{45}$ Whether or not it is impossible in theory, it is surely a difficult

41. My intuitions - and historical experience with prior "dangerous" copying technologies such as the VCR-point strongly to the position that owners of protected content are better off; but there really isn't enough evidence either way.

42. U.S. CONST. art. I, $\S 8$, cl. 8.

43. Remember, I am talking here about increases in the level of rights: protecting new subject matter for longer periods of time, criminalizing certain technologies, making it illegal to cut through digital fences even if they have the effect of foreclosing previously lawful uses, and so on. Each of these has the effect of diminishing the public domain in the name of national economic policy.

44. E.g., Boyle, Shamans, supra note 32; William M. Landes \& Richard A. Posner, An Economic Analysis of Copyright Law, 18 J. LEGAL STUD. 325, 348 (1989); Jessica Litman, The Public Domain, 39 EMORY L.J. 965, 1010-11 (1990); Pamela Samuelson \& Suzanne Scotchmer, The Law \& Economics of Reverse Engineering, 111 YALE L.J. 1575 (2002).

45. Sanford J. Grossman \& Joseph E. Stiglitz, On the Impossibility of Informationally Efficient Markets, 70 AM. ECON. REV. 393, 404 (1980). 
problem in practice. In other words, even if enclosure of the arable commons always produced gains (itself a subject of debate), enclosure of the information commons clearly has the potential to harm innovation as well as to support it. ${ }^{46}$ More property rights, even though they supposedly offer greater incentives, do not necessarily make for more and better production and innovationsometimes just the opposite is true. It may be that intellectual property rights slow down innovation, by putting multiple roadblocks, multiple necessary licenses, in the way of subsequent innovation. ${ }^{47}$ Using a nice inversion of the idea of the tragedy of the commons, Heller and Eisenberg referred to these effects - the transaction costs caused by myriad property rights over the necessary components of some subsequent innovation-as "The Tragedy of the Anticommons." ${ }^{48}$

IV

\section{INTELLECTUAL PROPERTY AND DISTRIBUTED CREATIVITY}

My arguments so far have taken as a given the incentives/collective action problems to which intellectual property is a response. I have discussed the extent to which the logic of enclosure works for the commons of the mind as well as it did for the arable commons, taking into account the effects of an information society and a global Internet. What I have not done is asked whether a global network actually transforms our assumptions about creativity and innovation so as to reshape the debate about the need for incentives, at least in certain areas. This, however, is exactly the question that needs to be asked.

For anyone interested in the way that networks can enable new collaborative methods of production, the free software movement, or the broader but less vociferous movement that goes under the name of open-source software, provide interesting case studies. ${ }^{49}$ Open-source software is released under a

46. For a more technical account, see James Boyle, Cruel, Mean, or Lavish?: Economic Analysis, Price Discrimination and Digital Intellectual Property, 53 VAND. L. REV. 2007 (2000) [hereinafter Boyle, Cruel].

47. The most recent example of this phenomenon is the multiple legal roadblocks to bringing "Golden Rice" to market. For a fascinating study of the various issues involved and the strategies for working around them, see R. David Kryder et al., The Intellectual and Technical Property Components of Pro-Vitamin A Rice (Golden Rice): A Preliminary Freedom-to-Operate Review, available at http:// www.isaaa.org/publications/briefs/Brief_20.htm (last visited Apr. 9, 2002). In assessing the economic effects of patents, one has to balance the delays and increased costs caused by the web of property rights against the benefits to society of the incentives to innovation, the requirement of disclosure, and the eventual access to the patented subject matter. When the qualification levels for patents are set too low, the benefits are minuscule and the costs very high - the web of property rights is particularly tangled, complicating follow-on innovation, the monopoly goes to "buy" a very low level of inventiveness, and the disclosure is of little value.

48. Michael A. Heller \& Rebecca S. Eisenberg, Can Patents Deter Innovation? The Anticommons in Biomedical Research, SCIENCE, May 1, 1998, at 698.

49. See Glyn Moody, Rebel Code: Linux And the Open Source Revolution (2001);

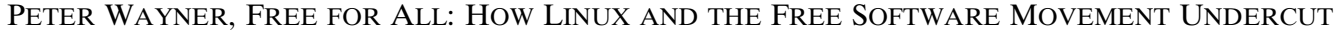
THE High-TECH-TITANS (2000); Eben Moglen, Anarchism Triumphant: Free Software and the Death of 
series of licenses, the most important being the General Public License ("GPL"). The GPL specifies that anyone may copy the software, provided the license remains attached and the source code for the software always remains available. $^{50}$ Users may add to or modify the code, may build on it and incorporate it into their own work, but if they do so, then the new program created is also covered by the GPL. Some people refer to this as the "viral" nature of the license; others find the term offensive. ${ }^{51}$ The point, however, is that the open quality of the creative enterprise spreads. It is not simply a donation of a program or a work to the public domain, but a continual accretion in which all gain the benefits of the program on pain of agreeing to give their additions and innovations back to the communal project.

The free software and open-source software movements have produced software that rivals and, many would say, exceeds the capabilities of conventional proprietary, binary-only software. ${ }^{52}$ Its adoption on the "enterprise level" is impressive, as is the number and enthusiasm of the various technical encomia to its strengths. The remarkable thing is not merely that the software works technically, but that it is an example of widespread, continued, high-quality innovation. The remarkable thing is that it works socially, as a continuing system, sustained only by a network consisting largely of volunteers. Here, it seems, we have a classic public good: code that can be copied freely and sold or redistributed without paying the creator or creators. This sounds like a tragedy of the commons of the kind that I described in the first section. Obviously, with a non-rival, non-excludable good like software, this method of production cannot be sustained; there are inadequate incentives to ensure continued production. E pur si muove, as Galileo is reputed to have said in the face of Cardinal Bellarmine's certainties, "And yet it moves." ${ }_{33}$

There is a broad debate on the reasons that the system works. Are the motivations those of the gift economy? Is this actually a form of potlatch, in which one gains prestige by the extravagance of the resources one "wastes?" Is open-source an implicit résumé builder that pays off in other ways? Is it driven by the species-being, the innate human love of creation that continually drives

Copyright, 4 FIRST MONDAY 8 (Aug. 2, 1999), at http:/firstmonday.org/issues/issue4_8/moglen/ index.html.

50. Proprietary, or "binary only," software is generally released only after the source code has been compiled into machine-readable object code, a form that is impenetrable to the user. Even if you were a master programmer, and the provisions of the Copyright Act, the appropriate licenses, and the DMCA did not forbid you from doing so, you would be unable to modify commercial proprietary software to customize it for your needs, remove a bug, or add a feature. Open source programmers say, disdainfully, that it is like buying a car with the hood welded shut. See, e.g., WAYNER, supra note 49, at 264.

51. See Brian Behlendorf, Open Source as a Business Strategy, in OPEN SOURCES: VOICES FROM THE OPEN SOURCE REVOLUTION, 149, 163 (Chris Dibona et al. eds., 1999).

52. See Bruce Brown, Enterprise-Level Security Made Easy, PC MAG., Jan. 15, 2002, at 28; Jim Rapoza, Open-Source Fever Spreads, PC WEEK, Dec. 13, 1999, at 1.

53. E. CobHam Brewer, The Dictionary of Phrase AND FABle, 1111-12 (1894). 
us to create new things even when homo economicus would be at home in bed, mumbling about public goods problems ? $^{54}$

Yochai Benkler and I would argue that these questions are fun to debate but ultimately irrelevant. ${ }^{55}$ Assume a random distribution of incentive structures in different people, a global network: transmission, information sharing and copying costs that approach zero, and a modular creation process. With these assumptions, it just does not matter why they do it. In lots of cases, they will do it. One person works for love of the species, another in the hope of a better job, a third for the joy of solving puzzles, and so on. Each person has his own reserve price, the point at which he says, "Now I will turn off Survivor and go and create something." But on a global network, there are a lot of people, and with numbers that big and information overhead that small, even relatively hard projects will attract motivated and skilled people whose particular reserve price has been crossed. For the whole structure to work without large-scale centralized coordination, the creation process has to be modular, with units of different sizes and complexities, each requiring slightly different expertise, all of which can be added together to make a grand whole. I can work on the sendmail program; you on the search algorithms. More likely, lots of people try, their efforts are judged by the community, and the best ones are adopted. Under these conditions, this curious mix of Kropotkin and Adam Smith, Richard Dawkins and Richard Stallman, we will get distributed production without having to rely on the proprietary/exclusion model. The whole enterprise will be much, much, much greater than the sum of the parts.

What's more, and this is a truly fascinating twist, when the production process does need more centralized coordination, some governance that guides how the sticky modular bits are put together, it is at least theoretically possible that we can come up with the control system in exactly the same way. In this sense, distributed production is potentially recursive. Governance processes, too, can

54. For a seminal statement, see Moglen, supra note 49:

"[I]ncentives" is merely a metaphor, and as a metaphor to describe human creative activity it's pretty crummy. I have said this before, but the better metaphor arose on the day Michael Faraday first noticed what happened when he wrapped a coil of wire around a magnet and spun the magnet. Current flows in such a wire, but we don't ask what the incentive is for the electrons to leave home. We say that the current results from an emergent property of the system, which we call induction. The question we ask is "what's the resistance of the wire?" So Moglen's Metaphorical Corollary to Faraday's Law says that if you wrap the Internet around every person on the planet and spin the planet, software flows in the network. It's an emergent property of connected human minds that they create things for one another's pleasure and to conquer their uneasy sense of being too alone. The only question to ask is, what's the resistance of the network? Moglen's Metaphorical Corollary to Ohm's Law states that the resistance of the network is directly proportional to the field strength of the "intellectual Id. property" system. So the right answer to the econodwarf is, resist the resistance.

55. Benkler's explanation is characteristically elegant, even formal in its precision, while mine is clunkier. See Yochai Benkler, Coase's Penguin, or, Linux and the Nature of the Firm, 111 YALE L.J. 369 (2002) [hereinafter Benkler, Coase's Penguin]. 
be assembled through distributed methods on a global network, by people with widely varying motivations, skills, and reserve prices. ${ }^{56}$

But in the language of computer programmers, does it "scale?" Can we generalize anything from this limited example? How many types of production, innovation, and research fit into the model I have just described? After all, for most innovations and inventions one needs hardware, capital investment, and large-scale real-world data collection-stuff, in its infinite recalcitrance and facticity. Maybe the open-source model has solved the individual incentives problem, but that's not the only problem. And how many types of innovation or cultural production are as modular as software? Is open-source software a paradigm case of collective innovation that helps us to understand open-source software and not much else?

Again, I think this is a good question, but it may be the wrong one. My own guess is that an open-source method of production is far more common than we realize. "Even before the Internet" (as some of my students have taken to saying portentously), science, law, education, and musical genres all developed in ways that are markedly similar to the model I have described. The marketplace of ideas, the continuous roiling development in thought and norm that our political culture spawns, is itself an idea that owes much more to the distributed, non-proprietary model than it does to the special case of commodified innovation that we think about in copyright and patent. Not that copyright and patent are unimportant in the process, but they may well be the exception rather than the norm. Commons-based production of ideas is hardly unfamiliar, after all.

In fact, all the mottoes of free software development have their counterparts in the theory of democracy and open society; "with enough eyeballs, all bugs are shallow" is merely the most obvious example. Karl Popper would have cheered. $^{57}$ The importance of open-source software is not that it introduces us to a wholly new idea; it is that it makes us see clearly a very old idea. With open source the technology was novel, the production process was transparent, and the result of that process was a "product" which out-competed other products in the marketplace. "How can this have happened? What about the tragedy of the commons?" we asked in puzzlement, coming only slowly to the realization that other examples of commons-based, non-proprietary production were all around us.

Still, this does not answer the question of whether the model can scale further. To answer that question we would need to think more about the modularity of other types of inventions-can they be broken down into chunks suitable for distribution among a widespread community? Which forms of innovation have some irreducible need for high capital investment in distinctly

56. One organization theorist to whom I mentioned the idea said, "Ugh, governance by food fight." Anyone who has ever been on an organizational listserv, a global production process run by people who are long on brains and short on social skills, knows how accurate that description is. E pur si muove.

57. See KArl Popper, The OPEn Society AND ItS ENEMIES (1945). 
non-virtual components-a particle accelerator or a Phase III drug trial? Again, my guess is that the increasing migration of the sciences towards dataand processing-rich models makes more innovations and discoveries potential candidates for the distributed model. Bio-informatics and computational biology, the open-source genomics project, ${ }^{58}$ the possibility of distributed data scrutiny by lay volunteers ${ }^{59}$ - all of these offer intriguing glances into the potential for the future. Finally, of course, the Internet is one big experiment in, as Benkler puts it, peer-to-peer cultural production. ${ }^{60}$

If these questions are good ones, why are they also the wrong ones? I have given my guesses about the future of the distributed model of innovation; my own utopia has it flourishing alongside a scaled-down, but still powerful, intellectual property regime. Equally plausible scenarios see it as a dead end, or as the inevitable victor in the war of productive processes. These are all guesses, however. At the very least, there is some possibility, even hope, that we could have a world in which much more of intellectual and inventive production is free. "'Free' as in 'free speech," Richard Stallman says, not "free' as in 'free beer." ", control and low cost or no cost. When the marginal cost of production is zero, the marginal cost of transmission and storage approaches zero, the process of creation is additive, and much of the labor doesn't charge-well, the world looks a little different. ${ }^{62}$ This is at least a possible future, or part of a possible future, and one that we should not foreclose without thinking twice. Yet that is what we are doing. The Database Protection Bills and Directives, which extend intellectual property rights to the layer of facts ${ }^{63}$ the efflorescence of software patents $;^{64}$ the UCITA-led validation of shrinkwrap licenses that bind third parties; ${ }^{65}$ the Digital Millennium Copyright Act's anti-circumvention provisions ${ }^{66}$ the point of all of these developments is not merely that they make the peer-topeer model difficult, but that in many cases they rule it out altogether. I will

58. See http://www.ensembl.org (last visited Sept. 18, 2002)

59. For example, NASA's “Clickworkers" experiment, which used public volunteers to analyze Mars landing data. See http://clickworkers.arc.nasa.gov/top (last visited September 30, 2002).

60. Benkler, Coase's Penguin, supra note 55 at 397.

61. Stallman, founder of the Free Software Foundation, describes this distinction at Website of the Free Software Foundation, at http://www.gnu.ai.mit.edu/philosophy/free-sw. html (last visited Dec. 19, 2002).

62. Exhibit A: the Internet-from the software and protocols on which it runs to the multiple volunteer sources of content and information.

63. See, e.g., The Consumer and Investor Access to Information Act of 1999, H.R. 1858, 106th Cong., § 101(1) (1999); Database Investment and Intellectual Property Antipiracy Act of 1996, H.R. 3531, 104th Cong. (1996); see also Directive, supra note 23.

64. See generally Julie E. Cohen \& Mark A. Lemley, Patent Scope and Innovation in the Software Industry, 89 CAL. L. REV. 1 (2001). See also Pamela Samuelson et al., A Manifesto Concerning the Legal Protection of Computer Programs, 94 ColUM. L. REV. 2308 (1994).

65. UNIF. COMPUTER INFO. TRANSACTIONS ACT (UCITA) (2001), available at http:// www.ucitaonline.com/ (last visited May 13, 2002).

66. 17 U.S.C. $\S 1201$ (2002). 
assert this point here, rather than argue for it, but I think it can be (and has been) demonstrated quite convincingly. ${ }^{67}$

The point is, then, that there is a chance that a new (or old, but under-recognized) method of production could flourish in ways that seem truly valuable-valuable to free speech, innovation, scientific discovery, the wallets of consumers, what William Fisher calls "semiotic democracy," ${ }^{68}$ and perhaps, valuable to the balance between joyful creation and drudgery for hire. True, it is only a chance. True, this theory's ambit of operation and its sustainability are uncertain. But why would we want to foreclose it? That is what the recent expansions of intellectual property threaten to do. And remember, these expansions were dubious even in a world where we saw little or no possibility of the distributed production model I have described, where discussion of network effects had yet to reach the pages of the New Yorker, ${ }^{69}$ and where our concerns about the excesses of intellectual property were simply the ones that Jefferson, Madison, and Macaulay gave us so long ago.

\section{$\mathrm{V}$ \\ BEYOND ENCLOSURE?}

Thus, we have come full circle. Is this the second enclosure movement? As I have tried to show, in many ways it is. The opponents and proponents of enclosure remain locked in battle, each appealing to conflicting and sometimes incommensurable claims about efficiency, innovation, justice, and the limits of the market. But should it be the second enclosure movement? Do we know that property rights in this sphere will yield the same surge of productive energy that is claimed for the enclosure of arable land ${ }^{70}$ There, I think the answer is a resounding "No." We rush to enclose ever-larger stretches of the commons of the mind without convincing economic evidence that it will help our processes

67. This point has been ably made, inter alia, by Pamela Samuelson, Jessica Litman, Jerry Reichman, Larry Lessig, and Yochai Benkler. See LITMAN, supra note 32; Benkler, Free as the Air, supra note 25; Pamela Samuelson, Intellectual Property and the Digital Economy: Why the Anti-Circumvention Regulations Need to be Revised, 14 BERKELEY TECH. L.J. 519, 566 (1999); J.H. Reichman \& Paul F. Uhlir, Database Protection at the Crossroads: Recent Developments and Their Impact on Science and Technology, 14 BERKELEY TECH. L.J. 793 (1999); Lawrence Lessig, Jail Time in the Digital Age, N.Y. TIMES, July 30, 2001, at A17. Each has a slightly different focus and emphasis on the problem, but each has pointed out the impediments now being erected to distributed, non-proprietary solutions. See also Boyle, Cruel, supra note 46.

68. William W. Fisher III, Property and Contract on the Internet, 73 CHI.-KENT L. REV. 1203, 121718 (1998).

69. See James Boyle, Missing the Point on Microsoft, SAlOn.COM, Apr. 7, 2000, at http://www. salon.com/tech/feature/2000/04/07/greenspan/index.html. [hereinafter Boyle, Missing the Point].

70. That is assuming that enclosure really did produce efficiency gains for arable land, though as I pointed out earlier, economic historians are now divided about that issue. See Allen, Efficiency, supra note 9. At best, one could say that the empirical evidence is equivocal. There are certainly reasons to believe that the commons, far from being tragic, was often relatively well managed. But the case for enclosure is at its strongest with arable land; even if one gives no weight at all to the contrary evidence there, the commons of the mind is very different and most of the differences cut strongly against the logic of enclosure-at least without considerably more evidence than we currently possess. 
of innovation and with very good reason to believe it will actually hurt them. ${ }^{71}$ As I have argued elsewhere, this second enclosure movement should bother people across the ideological spectrum, from civil libertarians to free marketeers; the world of the arts and sciences should be particularly interested in the process. The American system of science, for all its flaws, has worked astoundingly well. Changing some of its fundamental premises, such as by moving property rights into the data layer, is something not to be done lightly.

The dangers are particularly important at the moment for three reasons. First, propertization is a vicious circle. The argument is a little complex to lay out here ${ }^{72}$ but in essence the position is this: Once a new intellectual property right has been created over some informational good, the only way to ensure efficient allocation of that good is to give the rights holder still greater control over the user or consumer in the aftermarket so as to allow for price discrimination, since the only efficient monopoly is a monopoly with perfect price discrimination. $^{73}$ Yet, to achieve perfect price discrimination with digital intellectual property goods, whose marginal cost is zero, the rights holders will argue that they need even more changes of the rules in their favor: relaxed privacy standards so they can know more about our price points; enforceable shrinkwrap or clickwrap contracts of adhesion so that we can be held to the terms of our particular license, no matter how restrictive; and changes in antitrust rules to allow for a variety of practices that are currently illegal, such as resale price maintenance and various forms of tying. Rights holders will also claim that they need technical changes with legal backing, such as the creation of personalized digital objects surrounded by state-backed digital fences, objects that are tied to particular users and particular computers, so that reading my e-book on your machine is either technically impossible, a crime, or a tort-or possibly all three. The point of all this is that it is a slope that is much easier to go down than to come up. Thus, we ought to think clearly about the consequences of the decisions now being made in such a rush.

Second, in order to create the conditions for the kinds of price discrimination described above, the characteristics of the Internet that make it so attractive to civil libertarians-its distributed, anonymous character, its resistance to control or filtering by public or private entities, and its global nature-start to seem like bugs rather than features. The process of trying to make the Net safe for the price discrimination project has already begun; this, as Larry Lessig teaches us, is a fundamental public choice that ought to be made deliberately

71. Some of the legislation involved is also constitutionally dubious under the First Amendment and Copyright Clause. See Yochai Benkler, Through the Looking Glass: Alice and the Constitutional Foundations of the Public Domain, 66 LAW \& CONTEMP. PROBS. 173 (Winter/Spring 2003). This is particularly strange at a time when other government subsidies are subjected to relentless skepticism and demands for empirical support. Is it really worthwhile teaching poor pre-schoolers to read? Where is the data?

72. The full version is given in Boyle, Cruel, supra note 46.

73. Perfect price discrimination is the ability to charge every user the exact maximum of their ability and willingness to pay, so that the market can be perfectly segregated by price. 
and openly, not brought about imperceptibly as a side-effect of an economically dubious digital enclosure movement. ${ }^{74}$ Because of threats such as terrorism, we might choose to live in a pervasively monitored electronic environment in which identity, geography, and thus regulability, have been reintroduced, though in my own view the price would not be worth paying. But to do so on the basis of some bad microeconomic arguments about the needs of the entertainment industry, in the absence of good empirical evidence, and to foreclose some of the most interesting new productive possibilities in the process? Well, that would be really sad.

Third, the arguments in favor of the new enclosure movement depend heavily on the intellectually complacent, analytically unsound assumptions of the "neo-liberal orthodoxy," the "Washington Consensus." 75 The world of the Washington Consensus is divided into two parts. In one, growing smaller by the minute, are those portions of the economy where the government plays a major regulatory role. The job of neo-liberal economic thought is to push us toward the privatization of the few areas that remain; after all, we know that "state intervention in the economy" is a recipe for disaster. The second area of the Washington Consensus is an altogether happier place. This is the realm of well-functioning free markets, where the state does not regulate, subsidize, or franchise, but instead defines and protects property rights. While unintended consequences are rife in the world of government regulation, no such dangers should be feared if the government is simply handing over a patent on gene sequences or stem cell lines, or creating a property right over compilations of facts. Property is good, and more property is better. ${ }^{76}$ It would be ironic, to say the least, to maintain this view in the information commons, the one area where the delicate balance of the property system should be clearest and the political choices involved most obvious. It is doubly ironic to do so at a time when there are examples of modes of distributed production that stretch our sense of the economically possible, and that upset our complacency about the limited ways in which innovation and production can be managed.

But what is the alternative to the second enclosure movement? It is one thing to say, as I do, that we need more and better empirical information, and that our intellectual property system should be audited like any other government subsidy to make sure that we are getting what we pay for, and not paying too much for what we get. But the process I have described here is not entirely rational. In some cases, it is driven by industry capture of the levers of state power; in others, by a variety of alluring beliefs that dominate thought on the subject. The logic of enclosure ("Property saves lives! More incentives mean more production!") is the one I have concentrated on here. In other works, I have explored the impact of the ideal of original creation, creation ex nihilo, on

74. See Lawrence Lessig, The Future of IDEAs: The Fate of the Commons in A NETWORKED WORLD (2001).

75. See supra note 33.

76. See Boyle, Missing the Point, supra note 69. 
our assumptions about the need to protect the public domain. ${ }^{77}$ Who needs a public domain if you can create out of nothing? The point of this essay is that it is not enough merely to offer criticisms of the logic of enclosure. What is needed is deeper. We need a change in the way that these issues are understood, a change that transforms even our perceptions of self-interest, making possible coalitions where none existed before.

In the second half of this article, I try to develop the vocabulary and the analytic tools necessary to turn the tide of enclosure. I offer an historical sketch of various types of skepticism about intellectual property, from the antimonopolist criticisms of the Framers of the U.S. Constitution, through the emergence of affirmative arguments for the public domain, to the use of the language of the commons to defend the possibility of distributed methods of non-proprietary production. In many ways, it turns out, concepts of the public domain show the same variation in assumptions, and the same analytic differences, as the concept of property itself. I conclude by arguing that, for a number of reasons, the appropriate model for the change in thinking which I argue for comes from the history of the environmental movement. The invention of the concept of "the environment" pulls together a string of otherwise disconnected issues, offers analytical insight into the blindness implicit in prior ways of thinking, and leads to perception of common interest where none was seen before. Like the environment, the public domain must be "invented" before it is saved. Like the environment, like "nature," the public domain turns out to be a concept that is considerably more slippery than many of us realize. And, like the environment, the public domain nevertheless turns out to be useful, perhaps even necessary.

77. Boyle, Shamans, supra note 32; James Boyle, A Theory of Law and Information: Copyright, Spleens, Blackmail, and Insider Trading, 80 CAL. L. REV. 1413 (1992) [hereinafter Boyle, Theory]. 


\section{PART TwO: Against EnClosure}

\section{VI}

\section{ANTI-MONOPOLY AND A TAX ON READING}

Intellectual property has always had its critics-brilliant ones, at that, whose writing puts contemporary academics to shame. ${ }^{78}$ Thomas Jefferson leads off the list for American audiences. Writers from justices of the Supreme Court of the United States to John Perry Barlow quote Jefferson's 1813 letter to Isaac McPherson:

If nature has made any one thing less susceptible than all others of exclusive property, it is the action of the thinking power called an idea, which an individual may exclusively possess as long as he keeps it to himself; but the moment it is divulged, it forces itself into the possession of every one, and the receiver cannot dispossess himself of it. Its peculiar character, too, is that no one possesses the less, because every other possesses the whole of it. He who receives an idea from me, receives instruction himself without lessening mine; as he who lights his taper at mine, receives light without darkening me. That ideas should freely spread from one to another over the globe, for the moral and mutual instruction of man, and improvement of his condition, seems to have been peculiarly and benevolently designed by nature, when she made them, like fire, expansible over all space, without lessening their density in any point, and like the air in which we breathe, move, and have our physical being, incapable of confinement or exclusive appropriation. Inventions then cannot, in nature, be a subject of property. $^{79}$

Those who quote the passage sometimes stop here, which is a shame, because it leaves the impression that Jefferson was unequivocally against intellectual property rights. But that would be an overstatement. When Jefferson said that invention can never be a subject of property, he meant a permanent and exclusive property right which, as a matter of natural right, no just government could abridge. "Stable ownership is the gift of social law, and is given late in the progress of society. It would be curious then, if an idea, the fugitive fermentation of an individual brain, could, of natural right, be claimed in exclusive and stable property." $\$ 0$ This did not mean, however, that inventions could not be covered by temporary state-created monopolies, instituted for the common good. In the lines immediately following the popularly quoted excerpt, Jefferson goes on:

Society may give an exclusive right to the profits arising from [inventions], as an encouragement to men to pursue ideas which may produce utility, but this may or may not be done, according to the will and convenience of the society, without claim or complaint from any body. Accordingly, it is a fact, as far as I am informed, that England was, until we copied her, the only country on earth which ever, by a general law, gave a legal right to the exclusive use of an idea. In some other countries it is sometimes done, in a great case, and by a special and personal act, but, generally speaking, other nations have thought that these monopolies produce more embarrassment than

78. To be fair, this is not hard to do.

79. Letter from Thomas Jefferson to Isaac McPherson (Aug. 13, 1813), in 13 THE Writings OF THOMAs JefFERSON 326, 333-34 (Albert Ellery Bergh ed., 1907) [hereinafter Jefferson/McPherson Letter].

80. Id. at 333 . 
advantage to society; and it may be observed that the nations which refuse monopolies of invention, are as fruitful as England in new and useful devices. ${ }^{81}$

Jefferson's message was a skeptical recognition that intellectual property rights might be necessary, a careful explanation that they should not be treated as natural rights, and a warning of the monopolistic dangers that they pose. This message was famously echoed thirty years later in Britain by Thomas Babington Macaulay. Macaulay's speeches to the British Parliament in 1841 on the subject of copyright term extension still express better than anything else the position that intellectual property rights are necessary evils which must be carefully circumscribed by law. In order for the supply of valuable books to be maintained, authors "must be remunerated for their literary labor. And there are only two ways in which they can be remunerated. One of those ways is patronage; the other is copyright." ${ }^{\prime \prime 2}$ Patronage is rejected out of hand:

I can conceive no system more fatal to the integrity and independence of literary men than one under which they should be taught to look for their daily bread to the favour of ministers and nobles.... We have, then, only one resource left. We must betake ourselves to copyright, be the inconveniences of copyright what they may. Those inconveniences, in truth, are neither few nor small. Copyright is monopoly, and produces all the effects which the general voice of mankind attributes to monopoly. My honourable and learned friend talks very contemptuously of those who are led away by the theory that monopoly makes things dear. That monopoly makes things dear is certainly a theory, as all the great truths which have been established by the experience of all ages and nations, and which are taken for granted in all reasonings, may be said to be theories. It is a theory in the same sense in which it is a theory that day and night follow each other, that lead is heavier than water, that bread nourishes, that arsenic poisons, that alcohol intoxicates. If, as my honourable and learned friend seems to think, the whole world is in the wrong on this point, if the real effect of monopoly is to make articles good and cheap, why does he stop short in his career of change? Why does he limit the operation of so salutary a principle to sixty years? Why does he consent to anything short of a perpetuity? He told us that in consenting to anything short of a perpetuity he was making a compromise between extreme right and expediency. But if his opinion about monopoly be correct, extreme right and expediency would coincide. Or rather, why should we not restore the monopoly of the East India trade to the East India Company? Why should we not revive all those old monopolies which, in Elizabeth's reign, galled our fathers so severely that, maddened by intolerable wrong, they opposed to their sovereign a resistance before which her haughty spirit quailed for the first and for the last time? Was it the cheapness and excellence of commodities that then so violently stirred the indignation of the English people? I believe, Sir, that I may with safety take it for granted that the effect of monopoly generally is to make articles scarce, to make them dear, and to make them bad. And I may with equal safety challenge my honourable friend to find out any distinction between copyright and other privileges of the same kind; any reason why a monopoly of books should produce an effect directly the reverse of that which was produced by the East India Company's monopoly of tea, or by Lord Essex's monopoly of sweet wines. Thus, then, stands the case. It is good that authors should be remunerated; and the least exceptionable way of remunerating them is by a monopoly. Yet monopoly is an evil. For the sake of the good we must submit to the evil; but the evil ought not to last a day longer than is necessary for the purpose of securing the good. ${ }^{83}$

81. Id. at 334 .

82. Thomas B. Macaulay, A Speech Delivered in the House of Commons (Feb. 5, 1841), in VIII THE LIFE AND WORKS OF LORD MACAULAY 201 (London, Longmans, Green, and Co. 1897).

83. Id. 
These words from Jefferson and Macaulay encapsulate an eighteenth and nineteenth century free-trade skepticism about intellectual property. Jefferson himself believed that the Constitution should have definite limits on both the term and the scope of intellectual property rights ${ }^{84}$ and spoke of the difficulty of "drawing a line between the things which are worth to the public the embarrassment of an exclusive patent, and those which are not." ${ }^{.55}$ Madison, too, stressed the costs of any intellectual property right and the need to limit its term, ${ }^{86}$ as did Adam Smith. ${ }^{87}$ Their key concern was an anti-monopolistic one, though we should remember that for these men the concept of monopoly was a much richer one than the impoverished neo-classical economic concept we employ today. For them, monopoly involved not simply economic loss, though they certainly cared about that, but also the tendencies towards "corruption" that monopolies introduced. This corruption included the harm to the fabric of the republic caused by great concentrations of wealth and power as well as the perverse incentives given to the beneficiaries of state-granted monopolies to spend resources suborning the legislature on which their monopoly rent depended. Today, we call those incentives "campaign finance," "the participation of stakeholders in the legislative process," or just "business as usual."

The intellectual property skeptics had other concerns. Macaulay was particularly worried about the power that went with a transferable and inheritable monopoly. ${ }^{88}$ It is not only that the effect of monopoly is "to make articles

84. For example, in a letter to Madison commenting on the draft of the Constitution:

I like it, as far as it goes; but I should have been for going further. For instance, the following alterations and additions would have pleased me ... Article 9. Monopolies may be allowed to persons for their own productions in literature, and their own inventions in the arts, for a term not exceeding ___ years, but for no longer term, and no other purpose.

Letter from Thomas Jefferson to James Madison (Aug. 28, 1789), in 7 THE Writings OF ThOMAS

JEFFERSON 444, 450-51 (Albert Ellery Bergh ed., 1907).

85. Jefferson/McPherson Letter, supra note 79, at 355.

86. James Madison, Monopolies, Perpetuities, Corporations, Ecclesiastical Endowments, in Aspects of Monopoly One Hundred Years Ago, HARPER's MAG., Mar. 1914, at 489-90.

87. Smith says:

When a company of merchants undertake, at their own risk and expense, to establish a new trade with some remote and barbarous nation, it may not be unreasonable to incorporate them into a joint-stock company, and to grant them, in case of their success, a monopoly of the trade for a certain number of years. It is the easiest and most natural way in which the state can recompense them for hazarding a dangerous and expensive experiment, of which the public is afterwards to reap the benefit. A temporary monopoly of this kind may be vindicated, upon the same principles upon which a like monopoly of a new machine is granted to its inventor, and that of a new book to its author. But upon the expiration of the term, the monopoly ought certainly to determine; the forts and garrisons, if it was found necessary to establish any, to be taken into the hands of government, their value to be paid to the company, and the trade to be laid open to all the subjects of the state. By a perpetual monopoly, all the other subjects of the state are taxed very absurdly in two different ways: first, by the high price of goods, which, in the case of a free trade, they could buy much cheaper; and, secondly, by their total exclusion from a branch of business which it might be both convenient and profitable for many of them to carry on.

Adam Smith, Of the expenses of public works and public institutions, in III THE WEALTH OF NATIONS, 339 (London, Dent 1937) (1880).

88. Macaulay, supra note 82. 
scarce, to make them dear, and to make them bad." ${ }^{\prime 9}$ Macaulay also pointed out that those who controlled the monopoly, particularly after the death of the original author, might be given too great a control over our collective culture. Censorious heirs or purchasers of the copyright might prevent the reprinting of a great work because they disagreed with its morals. ${ }^{90}$ From more recent examples, we can also see that heirs may keep policing the boundaries of the work, attempting to prevent parody or tarnishment, long after the original author is dead. One wonders what Macaulay would have thought about the attempt by Margaret Mitchell's estate to prevent the publication of The Wind Done Gone. ${ }^{91}$

There were certainly other concerns raised about intellectual property in the eighteenth and nineteenth centuries. For example, while Macaulay is the best remembered critic of copyright in the debates of the 1840 s, there were other more radical opponents who saw copyright primarily as a "tax on literacy," identical in its effect to the newspaper stamp taxes. ${ }^{92}$ At a time when mass literacy and mass education were the hotly debated corollaries to the enlargement of the franchise, reformers looked with hostility on anything that seemed likely to raise the cost of reading and thus continue to restrict political and social debate to the wealthier classes. ${ }^{93}$

Patent law, too, attracted its share of attacks in the mid-nineteenth century. A fusillade of criticism, often delivered by economists and cast in the language of free trade, portrayed the patent system as actively harmful.

At the annual meeting of the Kongress deutscher Volkswirthe held in Dresden, September 1863, the following resolution was adopted "by an overwhelming majority:" "Considering that patents hinder rather than further the progress of invention; that they hamper the prompt general utilisation of useful inventions; that on balance they cause more harm than benefit to the inventors themselves and, thus, are a highly deceptive form of compensation; the Congress of German Economists resolves: that patents of invention are injurious to common welfare." ${ }^{, 4}$

89. Id.

90. In a speech to the house of commons, Macaulay said:

These are strong cases. I have shown you that, if the law had been what you are now going to make it, the finest prose work of fiction in the language, the finest biographical work in the language, would very probably have been suppressed. But I have stated my case weakly. The books which I have mentioned are singularly inoffensive books, books not touching on any of those questions which drive even wise men beyond the bounds of wisdom. There are books of a very different kind, books which are the rallying points of great political and religious parties. What is likely to happen if the copyright of one of these books should by descent or Id. transfer come into the possession of some hostile zealot?

91. The Mitchell estate attempted to block publication of The Wind Done Gone by Alice Randall, a work which retold Gone With the Wind from the slaves' perspective. The Eleventh Circuit reversed a preliminary injunction blocking publication. SunTrust Bank v. Houghton Mifflin Co., 268 F.3d 1257 (11th Cir. 2001).

92. See CATHERINE SEVILlE, LiterARY COPYRIGHT REFORM IN EARLY ViCTORIAN ENGLAND: THE FRAMING OF THE 1842 COPYRIGHT ACT 46-48 (1999).

93. Id. at 48.

94. Fritz Machlup \& Edith Penrose, The Patent Controversy in the Nineteenth Century, $10 \mathrm{~J}$. ECON. HIST. 1, 4 n.8 (1950). 
In the Netherlands, the patent system was actually abolished in 1869 as a result of such criticisms. ${ }^{95}$ Observers in a number of other countries, including Britain, concluded that their national patent systems were doomed. ${ }^{96}$ Various proposals were made to replace patent, with state-provided prizes or bounties to particularly useful inventions being the most popular. ${ }^{97}$

These snippets are hardly sufficient to constitute any kind of a survey of critical reactions to intellectual property systems, but I believe that nevertheless they give a relatively fair sense of the debate. Three points could be made.

First, from the early days of intellectual property as we now know it, the main objections raised against it were framed in the language of free trade and anti-monopoly. In the United States, the founding generation of intellectuals had been nurtured on the philosophy of the Scottish Enlightenment and the history of the struggle against royal monopolies. They were not immune to the arguments in favor of intellectual property, but they repeatedly warned of the need to circumscribe both its term and its scope. What were their concerns? They worried about intellectual property producing artificial scarcity, high prices, and low quality. They worried about its justice; given that we all learn from and build on the past, do we have a right to carve out our own incremental innovations and protect them by intellectual property rights? ${ }^{98}$ Price aside, they also worried that intellectual property (especially with a lengthy term) might give too much control to a single individual or corporation over some vital aspect of science and culture. In more muted fashion, they discussed the possible effects that intellectual property might have on future innovation. But the overwhelming theme was the promotion of free trade and a corresponding opposition to monopolies.

Second, it is important to look at the structure of these comments by Jefferson, Macaulay, and others; they are framed as criticisms of intellectual property rather than defenses of the public domain or the commons, terms that appear rarely, if at all, in the debates. There is no real discussion of the world outside of intellectual property, its opposite, whether in conceptual or economic terms.

Third, a linked point: Most of these critics take as their goal the prevention or limitation of an "artificial" monopoly. Without this monopoly, our goal is to

95. Id. at 5 .

96. Id. at 1 .

97. Christine MACLeOd, InVEnting the Industrial ReVOlution 191-96 (1988). Ironically, contemporary economists are rediscovering the attraction of patent alternatives. See Steven Shavell \& Tanguy Van Ypersele, Rewards versus Intellectual Property Rights, Working Paper 6956, available at http://www.nber.org/papers/w6956 (last visited Jan. 14, 2003).

98. Benjamin Franklin recalled that:

Gov'r. Thomas was so pleas'd with the construction of this stove ... that he offered to give me a patent for the sole vending of them for a term of years; but I declin'd it from a principle which has ever weighed with me on such occasions, viz.: That, as we enjoy great advantages from the inventions of others, we should be glad of an opportunity to serve others by any invention of ours; and this we should do freely and generously.

Benjamin Franklin, Autobiography (1771), in THE WORKS OF BENJAMIN FRANKLIN 1, 237-238 (John Bigelow ed., 1904). 
have a world of ... what? The assumption is that we will return to a norm of freedom, but of what kind? Free trade in expression and innovation, as opposed to monopoly? Free access to innovation and expression, as opposed to access for pay? Or free access to innovation and expression in the sense of not being subject to the right of another person to pick and choose who is given access, even if all have to pay some flat fee? Or is it common ownership and control that we seek, including the communal right to forbid certain kinds of uses of the shared resource? The eighteenth and nineteenth century critics brushed over these points, but to be fair, we continue to do so today.

\section{VII}

\section{ReCognizing The PUblic Domain}

In the last section, I discussed the anti-monopolist criticisms of intellectual property law, criticisms that were heard from the beginning of intellectual property in its modern form and which continue to the present day. At what point does the negative account of the ills of intellectual property turn into, or get added to, a defense of something called "the public domain?"

By a defense of the public domain, I do not mean mere usage of the word. Though "public domain" was a term widely used to describe public lands in the United States, the intellectual property usage of the term comes to us from the French domaine public which made its way into American law in the late nineteenth century via the language of the Berne Convention. ${ }^{99}$ But at what point do we find a defense of the public domain, rather than merely a criticism of the costs of intellectual property?

Many different starting points are defensible. In the United States, the work of Ralph Brown and Ben Kaplan is sometimes mentioned as initiating this way of looking at things. ${ }^{100}$ The Supreme Court itself can plausibly be given some credit. $^{101}$ In a 1966 patent case, repeatedly citing the work of Jefferson, the Court made it clear that the public domain has a constitutional dimension:

The Congress in the exercise of the patent power may not overreach the restraints imposed by the stated constitutional purpose. Nor may it enlarge the patent monopoly without regard to the innovation, advancement or social benefit gained thereby. Moreover, Congress may not authorize the issuance of patents whose effects are to remove existent knowledge from the public domain, or to restrict free access to materials already available. ${ }^{102}$

This is a remarkable statement. It goes beyond a mere recitation of the Framers' attitude toward the dangers posed by monopoly, and makes an affirmative defense of the public domain. Notice how the limitations are stated

99. See Litman, supra note 44. The process is somewhat ironic, since the French copyright law, with its focus on author's rights, is in many ways among the least solicitous and protective of the public domain.

100. See Litman, supra note 32; Edward Samuels, The Public Domain in Copyright Law, $41 \mathrm{~J}$. COPYRIGHT SOC. 137, 150 (1993).

101. I admit this is an unusual admission from a legal academic.

102. Graham v. John Deere Co., 383 U.S. 1, 5-6 (1966). 
as additive and not as mutually equivalent, or even as mere corollaries; the Court does not say that "the enlargement of the patent monopoly must promote innovation and this limits Congress's power to remove material from the public domain." Instead, it postulates an existent public domain and makes it unconstitutional under the patent clause for Congress to privatize any portion of that domain. There are echoes here of the "public trust doctrine," which restricts the state's ability to privatize public resources or waterways and turn them over to private parties. ${ }^{103}$ Notice also that the Court gives the public domain both direct and indirect protection: Protection from measures which formally create patent rights over portions of the public domain, but also from those which merely "restrict free access to materials already available." "104

Thus, there are a number of possible places where one could say, "the defense of the public domain begins here." But, like most people, I attribute central importance to the writing of my friend and colleague David Lange, whose article Recognizing the Public Domain really initiated contemporary study of the subject. ${ }^{105}$ Lange's article was driven by indignation about, indeed eloquently sarcastic ridicule of, expansions of intellectual property protection in the 1960s and 1970s. ${ }^{106}$ Lange claims that one major cause of this expansion was that intellectual property rights are intangible, abstract, and thus, imprecise. ${ }^{107}$ He argues, in a way that would have been familiar to Macaulay or Jefferson, that we should cease the reckless expansion. ${ }^{108}$ But he also argues that "recognition of new intellectual property interests should be offset today by equally deliberate recognition of individual rights in the public domain." ${ }^{109}$

Lange is not arguing:
that intellectual property is undeserving of protection, but rather that such protection as it gets ought to reflect its unique susceptibility to conceptual imprecision and to infinite replication. These attributes seem to me to require the recognition of two fundamental principles. One is that intellectual property theory must always accept something akin to a "no-man's land" at the boundaries; doubtful cases of infringement ought always to be resolved in favor of the defendant. The other is that no exclusive interest should ever have affirmative recognition unless its conceptual opposite is also recognized. Each right ought to be marked off clearly against the public domain. ${ }^{110}$

But what does this mean? What is the nature of these "individual rights in the public domain?" Who holds them? Indeed, what is the public domain? Does it consist only of works that are completely unprotected, say books whose copy-

103. Carol Rose, The Comedy of the Commons: Custom, Commerce, and Inherently Public Property, 53 U. CHI. L. REV. 711, 727-28 (1986).

104. Graham, 383 U.S. at 6.

105. David Lange, Recognizing the Public Domain, 44 LAW \& ConTEMP. Probs. 147 (Autumn 1981).

106. Id. at 151-71.

107. For example, in one memorable discussion of a hypothetical drawn from Tom Wolfe: "I think it is useful to remember, however, that what we are talking about, insofar as our senses can perceive it, is still a wet spot on the dead wino's napkin. Everything else is hypothesis." Id. at 149.

108. Id. at 147 .

109. Id.

110. Id. 
right term has lapsed? Does it include aspects of works that are unprotectable, such as the ideas or the facts on which an argument is based, even if the expression of that argument is protected? What about limitations on exclusive rights, privileges of users, or affirmative defenses-are those part of the public domain too? Is the parody-able aspect of your novel in the public domain? What about the short quote on which a critical argument is mounted? Earlier in this article, I discussed the "commons of the mind." What is the relationship between the public domain-however defined-and the commons? ${ }^{112}$ If the public domain is so great, why? What does it do for us? What is its role? These questions can be reduced to two: (1) What is the public domain?, and (2) Why should we focus on it? In the following pages, I will argue that the answer to the first question depends on the answer to the second.

Work that followed Lange's article offered various answers to the questions he had posed. For example, Lindberg and Patterson's book The Nature of Copyright reverses the polarity from the normal depiction, and portrays copyright as a law of users' rights. ${ }^{113}$ The public domain is the figure and copyright the ground. The various privileges and defenses are not exceptions, they are at the heart of copyright, correctly understood. Copyright is, in fact, a system designed to feed the public domain providing temporary and narrowly limited rights, themselves subject to considerable restrictions even during their existence-all with the ultimate goal of promoting free access.

Jessica Litman's fine 1990 article, The Public Domain, portrays the public domain's primary function as allowing copyright law to continue to work notwithstanding the unrealistic, individualistic idea of creativity it depends on:

The public domain rescues us from this dilemma. It permits us to continue to exalt originality without acknowledging that our claims to take originality seriously are mostly pretense. It furnishes a crucial device to an otherwise unworkable system by reserving the raw material of authorship to the commons, thus leaving that raw material available for other authors to use. The public domain thus permits the law of

111. See supra Part II.

112. Non-lawyers, who are (rightly) skeptical of definitional inquiries and doubly skeptical of lawyers engaged in definitional inquiries, might believe these points are at best semantic and at worst essentialist. They could be right. We might take what Felix Cohen said about definitions of law and apply them to definitions of the public domain.

A definition of [the public domain] is useful or useless. It is not true or false, any more than a

New Year's resolution or an insurance policy. A definition is in fact a type of insurance against certain risks of confusion. It cannot, any more than can a commercial insurance policy, eliminate all risks.

Felix Cohen, Transcendental Nonsense and the Functional Approach, 35 COLUM. L. REV. 809, 835-36 (1935). Wittgenstein is equally eloquent in pointing out the dangers of seeking the one true definition:

Naming appears as a queer connexion of a word with an object.-And you really get such a queer connexion when the philosopher tries to bring out the relation between name and thing by staring at an object in front of him and repeating a name or even the word "this" innumerable times. For philosophical problems arise when language goes on holiday.

Ludwig Wittgenstein, Philosophical InVestigations 19 (1958). I am asking for a ten-page suspension of disbelief while I pursue the question.

113. L. Ray Patterson \& Stanley W. Lindberg, The Nature of Copyright: A LaW of USERS' RIGHTS (1991). 
copyright to avoid a confrontation with the poverty of some of the assumptions on which it is based. ${ }^{11}$

Litman's definition of the public domain is both clear and terse: "[A] commons that includes those aspects of copyrighted works which copyright does not protect." 115 Precisely because she sees the function of the public domain as allowing the kinds of additive and interstitial creation that the language of individual originality fails to capture, her definition of the public domain includes the recyclable, unprotected elements in existing copyrighted works as well as those works that are not protected at all. Form follows function.

Yochai Benkler takes a slightly different approach. He follows Litman in rejecting the traditional, absolutist conception of the public domain, a conception which included only those things that are totally unprotected by copyright:

The particular weakness of the traditional definition of the public domain is that it evokes an intuition about the baseline, while not in fact completely describing it. When one calls certain information "in the public domain," one means that it is information whose use, absent special reasons to think otherwise, is permissible to anyone. When information is properly subject to copyright, the assumption (again absent specific facts to the contrary) is that its use is not similarly allowed to anyone but the owner and his or her licensees. The limited, term-of-art "public domain" does not include some important instances that, as a descriptive matter, are assumed generally to be permissible. For example, the traditional definition of public domain would treat short quotes for purposes of critical review as a fair use-hence as an affirmative defense-and not as a use in the public domain. It would be odd, however, to describe our system of copyright law as one in which users assume that they may not include a brief quotation in a critical review of its source. I venture that the opposite is true: Such use generally is considered permissible, absent peculiar facts to the contrary. ${ }^{116}$

Benkler's alternative definition, however, does not include every privileged use-such as, for example, the fair use privilege that I am able to vindicate only after litigating an intensely complicated case that involves highly specific factual inquiries.

The functional definition therefore would be: The public domain is the range of uses of information that any person is privileged to make absent individualized facts that make a particular use by a particular person unprivileged. Conversely, $[\mathrm{t}] \mathrm{he}$ enclosed domain is the range of uses of information as to which someone has an exclusive right, and that no other person may make absent individualized facts that indicate permission from the holder of the right, or otherwise privilege the specific use under the stated facts. These definitions add to the legal rules traditionally thought of as the public domain, the range of privileged uses that are "easy cases."

The key to Benkler's analysis is his focus on the public domain's role in information production and use by all of us in our roles as consumers, citizens, and future creators. We need to focus on those works, and aspects of works, that the public can know to be free without having to go through a highly individualized factual inquiry. "Free" meaning what? Earlier in this essay, I asked what we mean when we speak of the freedom that the public domain will

114. Litman, supra note 44 , at 1023.

115. Id. at 968 .

116. Benkler, Free as the Air, supra note 25, at 361-62.

117. Id. 
allow. ${ }^{118}$ Free trade in expression and innovation, as opposed to monopoly? Free access to expression and innovation, as opposed to access for pay? Or free access to innovation and expression, in the sense of not being subject to the right of another person to pick and choose who is given access, even if all have to pay some flat fee? Or is it common ownership and control that we seek, including the communal right to forbid certain kinds of uses of the shared resources? I think that Benkler is arguing that the most important question here is whether lay people would know that a particular piece or aspect of information is free-in the sense of being both uncontrolled by anyone else and costless.

The test case is simple to imagine: Do we count as part of the public domain songs that can be "covered" by subsequent artists upon payment of a defined fee under a compulsory license? To put it in the language of legal theory, is content that is covered only by "liability rules" 119 actually part of the public domain? Well, of course that depends on why we care about the public domain, on what vision of freedom or creativity we think the public domain stands for, and what danger it protects against. The public domain will change its shape according to the hopes it embodies, the fears it tries to lay to rest, and the implicit vision of creativity on which it rests. There is not one public domain, but many.

What is true for the public domain turns out to be true also for the third and final language that seeks to circumscribe and offer limits to the enclosure movement: the language of the commons. The "commons" is a term that has come to be used increasingly often over the last five years to refer to wellsprings of creation that are outside of, or different from, the world of intellectual property. The Internet was seen as such a commons. The Internet expanded so rapidly precisely because its core protocols, TCP/IP and HTML, are open; like languages, these systems allowed all to create by offering a common framework owned by no one. And that insight, coupled with the positive images of communal production that the Net offered and the negative images of networkeffect leveraged monopolies that the Net also offered galvanized a related but different type of interest in "the outside of property." It is to the commons that I will now turn.

\section{VIII}

\section{DISCOVERING THE E-COMMONS}

Let us start with Larry Lessig's definition of a commons:

It is commonplace to think about the Internet as a kind of commons. It is less commonplace to actually have an idea what a commons is. By a commons I mean a resource that is free. Not necessarily zero cost, but if there is a cost, it is a neutrally imposed, or equally imposed cost. Central Park is a commons: an extraordinary resource of peacefulness in the center of a city that is anything but; an escape and

118. See supra Part VI.

119. In particular, I refer to statutory liability rules with pre-specified payments. 
refuge, that anyone can take and use without the permission of anyone else. The public streets are a commons: on no one's schedule but your own, you enter the public streets, and go any direction you wish. You can turn off of Broadway onto Fifty-second Street at any time, without a certificate or authorization from the government. Fermat's last theorem is a commons: a challenge that anyone could pick up; and complete, as Andrew Wiles, after a lifetime of struggle, did. Open source, or free software, is a commons: the source code of Linux, for example, lies available for anyone to take, to use, to improve, to advance. No permission is necessary; no authorization may be required. These are commons because they are within the reach of members of the relevant community without the permission of anyone else. They are resources that are protected by a liability rule rather than a property rule. Professor Reichman, for example, has suggested that some innovation be protected by a liability rule rather than a property rule. The point is not that no control is present; but rather that the kind of control is different from the control we grant to property. ${ }^{120}$

Note the difference in focus between Lessig and Benkler. If our concern is monopolistic control over choke-points imposed by the will of others, freedom from others "telling us what we can do," then the norm of freedom we will seek to instantiate in property's outside, whether we describe it as a public domain or a commons, is a norm of non-discriminatory access. Freedom in one powerful liberal tradition means freedom from the will of another, not freedom from the background constraints of the economic system. ${ }^{121}$ Why pick this vision of freedom instead of the vision provided by Benkler's account of the public domaincontent that is literally "free," both free from exclusive rights, and available at zero cost? ${ }^{122}$ There are lots of reasons. In the world of "network effects," an intellectual property right over a widely used standard or network protocol can give an unprecedented amount of power to the rightholder; the power might even include the ability to leverage one's rights to stifle innovation that threatens one's business. The Microsoft case is an obvious example. ${ }^{123}$ The complaint against the Microsofts of the world is not so much that they keep their prices high-though that is sometimes alleged. Instead it is the claim that their intellectual property rights over fundamental standards with strong positive network effects give them too much power to control the course of innovation.

As the dysfunctional side of property/monopoly comes to be seen as a restraint on innovation rather than a problem of price gouging, correspondingly, property's outside-"not property"-shifts its core characteristics. If one's main concern is maintaining innovation, one might think that the danger

120. Larry Lessig, The Architecture of Innovation, 51 DUKE L. J. 1783, 1788 (2002).

121. Which is not to say that this is Lessig's only concern. See LAWRENCE LESSIG, CODE AND OTHER LAWS OF CYBERSPACE (1999) (focusing particularly on "material," code-based restraints imposed by the architecture of communications networks, and arguing that choices within and among different potential architectures should be subject to more democratic and constitutional scrutiny); see also James Boyle, Foucault in Cyberspace: Surveillance, Sovereignty and Hard-Wired Censors, 66 U. CIN. L. REV. 177 (1997) [hereinafter Boyle, Foucault].

122. See supra Part VII.

123. It is only fair to point out, however, that both the particular claims and the general economic observations about strong network effects and "path dependency" have been hotly disputed by Microsoft and independent academics. For a marvelously readable example, see Stephan E. Margolis \& Stan Liebovitz, We Don't Know Why She Swallowed The Fly: Policy and Path Dependence, at http:// www.utdallas.edu/ liebowit/regulatn.html (last visited Jan. 14, 2003). 
of monopoly here is not higher prices, but rather the power of control itself; access to the intellectual property in question on payment of a flat fee might seem to avoid those dangers and to allow for free competition in follow-on innovation. The world of monopoly and property comes to be seen as a world of restraint on innovation, more than a world of restricted output and high prices. In technical terms, an imagined commons of pure Hohfeldian privileges gives way to a commons partly constituted of resources protected by liability rules. ${ }^{124}$ The "opposite of property" comes to be defined as "that which will cure monopoly control of standards with strong network effects" rather than that which is not owned, or is owned by all. In describing the possibility of open standards with which all can work, the language of the commons apparently resonates better than the language of the public domain.

But I suspect that there is a second reason for the way in which "commons" and "public domain" now jockey for position as the instantiation of intellectual property's "outside." Although we present our reasoning on these matters in neat chains of apparently logical argument, our doing so conceals the power of "the paradigm case," 125 the core example, or irresistible counter-example, in shaping our ideas.

As I argued in the first part of this essay, most recent theorists of the public domain start with the irresistible example of the free and open-source software movements before their eyes. ${ }^{126}$ Here was a real-world spur to rethink the public goods problem, the tragedy of the commons, on which the economic rationale for intellectual property rights was based. Here was a "comedy of the commons." 127 To be sure, the claim was not that open-source or free software would provide a model that rendered all intellectual property unnecessary. There would still be an enclosed domain; the open source model would not work everywhere. ${ }^{128}$ But now, the placement of the line between the two domains was everywhere up for grabs. This is a point that cannot be stressed enough. There was one small problem, however. Though open-source software is of particular interest to those concerned about the worldwide expansion of intellectual property rights, it is by no means clear how it fits into the binary opposition between intellectual property on the one hand and the public domain on the other.

124. For the most important statement of the value of liability rules in promoting follow-on innovation, see J.H. Reichman, Of Green Tulips and Legal Kudzu: Repackaging Rights in Subpatentable Innovation, 53 VAND. L. REV. 1743 (2000). Reichman does not, however, take a position on whether to define the information goods protected by liability rules as part of the commons.

125. I owe this insight to Jed Rubenfeld, The First Amendment's Purpose, 53 StAn. L. REV. 767 (2001).

126. See supra Part IV.

127. I borrow the phrase from the title of Carol Rose's magnificently prescient article which discusses the occasional superiority of common property regimes to individual private property rights. See Rose, supra note 103; see also Carol Rose, The Several Futures of Property: Of Cyberspace and Folk Tales, Emission Trades and Ecosystems, 83 MINN. L. REV. 129, 155-56 (1998).

128. See supra Part IV. 
Though journalists frequently and mistakenly claim otherwise, neither "free software," nor most "open-source software" is in the public domain. After all, the thing that makes open-source software work is the General Public License. ${ }^{129}$ All the things that seem so interesting about open-source-its model of distributed production, the way it grows, binding future innovators who make use of it to add to the store themselves-are built on this license. ${ }^{130}$ That license, in turn, rests on an intellectual property right, the copyrights held by the Free Software Foundation and other entities. ${ }^{131}$ The GPL says, in effect: Here is this copyrighted body of work; you may use it, add to it, modify it, or copy it-all of these uses are legal, but only if you comply with the terms of the GPL. Otherwise, your actions are infringements of the exclusive rights conferred by section 106 of the Copyright Act. ${ }^{132}$ If, for example, you take the Linux kernel, fiddle with it, add your own material, and attempt to sell the result as proprietary, binary-only software, you have violated the GPL license which gives you permission to reproduce this copyrighted material in the first place. In legal terms, at least, the free software movement stands squarely on intellectual property.

Given that free software stands as the kind of "irresistible example" around which theories tend to form, how is it to be assimilated into the older criticisms of intellectual property and defenses of the public domain? The free software movement, at least, was formed explicitly around criticisms of the effects of intellectual property that would have been familiar to Jefferson and Macaulay. ${ }^{133}$ The answer to the perceived negative effects of strong intellectual property rights on innovation and freedom, however, was not to write a lot of code and release it unprotected by copyright. Instead, the free software movement attempted to build a living ecology of open code, where the price for admission was your commitment to make your own incremental innovation part of the ecology. ${ }^{134}$ On the one hand, this fit poorly into the old model of the "total freedom" public domain; there were, after all, significant restraints on use of the software, restraints that were vital to the project. On the other hand, however, it fit very well into a new literature on governing the commons from Elinor Ostrom, Robert Keohane, Margaret McKean, and many others. ${ }^{135}$ This litera-

129. GNU Library General Public License, available at http://www.gnu.org/copyleft/library.txt (last visited Jan. 14, 2003).

130. Id.

131. Id.

132. 17 U.S.C. $\$ 106(1994)$.

133. See supra Part VI.

134. An alternative approach, the Free BSD License, is closer to a mainstream understanding of public domain software. BSD License, available at http://www.opensource.org/licenses/bsd-license.html (last visited Jan. 14, 2003). The user is free to do anything with software covered by this license, including adding to it and selling the resultant program in a proprietary, binary-only format.

135. See, e.g., SusAn BucK \& Elinor Ostrom, The Global COMMONS (1998); Local COMMONS AND GLOBAL INTERDEPENDENCE: HETEROGENEITY AND COOPERATION IN TWO DOMAINS (Elinor Ostrom \& Robert Keohane eds., 1994); MARGARET MCKEAN, MAKING THE COMMONS WORK: THEORETICAL, HISTORICAL, AND CONTEMPORARY STUDIES (David Bromley et al. eds., 1992); ElinOR OSTROM, GOVERNING THE COMMONS: THE EVOLUTION OF INSTITUTIONS FOR Collective ACtion (1991); Margaret McKean, Success on the Commons: A Comparative 
ture was able to show that not every commons was a tragedy. But the literature also showed that successful commons were not entirely "free"-they ran on layers of norms that were frequently invisible to the legal system, but which nevertheless served to avoid the various paradoxes of collective action. Whether the examples were Japanese herdsmen or Silicon Valley programmers, the literature seeks to show just how the commons was, and should be, governed. ${ }^{136}$

Notice the differences in approach. The old dividing line in the literature on the public domain had been between the realm of property and the realm of the free. ${ }^{137}$ The new dividing line, drawn on the palimpsest of the old, is between the realm of individual control and the realm of distributed creation, management, and enterprise. To be sure, the two projects share a great deal, but they are also different in important ways. To put it bluntly, some of the theorists of the e-commons do not see restraints on use as anathematic to the goal of freedom; indeed, they may see the successful commons as defined by its restraints. ${ }^{138}$ Those restraints may be legal-Lessig's liability rules-or they may be built on community norms and prestige networks of various kinds. The point is that "property's outside," property's antonym, was now being conceived of differently, though frequently, and somewhat confusingly, using the same words and many of the same arguments.

Examination of Institutions for Common Property Resource Management, 4 J. OF THEORETICAL POL. 247 (1992); Elinor Ostrom, Reformulating the Commons, 6 SwISS POL. SCI. REV., Apr. 15, 1999, at 29.

136. One of the most interesting attempts to revive the notion of the commons and apply it to contemporary intellectual property policy issues comes from David Bollier. Bollier's concerns go well beyond using intellectual property to deal with many different types of public assets. See, e.g., David Bollier, Public Assets, Private Profits, available at http://www.bollier.org/pdf/PA_Report.pdf (last visited Feb. 13, 2003). Nevertheless he also places a very strong emphasis on the public domain and the information commons. See David Bollier, Recent Works, available at http://www.bollier.org/recent.htm (last visited Feb. 13, 2003).

137. See supra Part VI, recognizing a lot of ambiguities in the term "free."

138. Yochai Benkler wrote:

[B]y limiting implementation of information policy to focus on two institutional devices, privatization and direct regulation, we have limited the potential for decentralization of information production in our society. Introducing a third institutional device, the commons, is likely to increase the degree of decentralization that can be sustained within the institutional constraints our society imposes on information production and exchange. Two efforts are necessary in order to introduce commons as a stable element in our information environment. First, it is necessary to identify information and communications inputs that, like radio frequency spectrum and some information, can be used without being subject to the exclusive control of any governmental or non-governmental organization. Second, it is necessary to undertake the design of the institutional constraints necessary to take advantage of the economic or technological attributes that make these inputs susceptible to being used on a commons model. These tasks are important avenues to serving two commitments our society has traditionally located in the first amendment.

Yochai Benkler, The Commons As A Neglected Factor of Information Policy (1998), available at http:// www.law.nyu.edu/benklery/commons.pdf (last visited Dec. 19, 2002) (emphasis added). 


\section{IX}

\section{DisAggregating Freedom: A Legal ReAlism For the PUblic DomAin}

This has been very long way of answering a short question. (I am an academic after all.) What are the alternatives to, and the critiques of, the second enclosure movement? I have sketched out three projects here: an antimonopolistic critique of intellectual property, a defense of "a free public domain," and an attempt to outline the rules for a commons of the mind on the global net. These three projects overlap, draw from similar philosophical and economic sources, and use the same vocabulary. They are also not necessarily consistent with each other, and each may use the same term in different ways. "Free," "public domain," "commons," "enclosure"-each term shifts its meaning as we move from one intellectual project to the next, in part because each project is built around a different set of hopes and fears.

The first stage of the story I outlined here was the attempt by Jefferson, Madison, Macaulay, and others to balance the arguments in favor of intellectual property with criticism of its monopolistic costs and dangers; the goal was to build an awareness of the need for limitations into the grant itself. The second stage was a little more complex. Here, an affirmative argument for the public domain was put forward, rather than a mere criticism of intellectual property. There was an existent public domain, whose value we should recognize and which should have protection-perhaps even constitutional protection-against the danger that knowledge would be removed from it, or access to existing material impeded. Fine and dandy, but what was this public domain that we were to protect? There the answers were less clear. What norm of freedom did the public domain instantiate? Free trade? Free beer? Freedom from monopolistic control? Free communal production? The early public domain theorists were enigmatic on this point; the later ones vocal, but not necessarily consistent. The final panel in my triptych still relies on the criticisms of enclosure and monopoly, but in the place of the public domain, we find the rhetoric of the commons, a commons that in some conceptions one might have to pay to use.

At first sight, this may all seem distressingly messy. Surely, conceptions of the public domain, or the commons, should be more consistent. Why so much variation, such different definitions? Look at the question from the other side of the looking glass. Is this little potted history so very different from the history of the concept of property? We know very well that concepts of property have varied enormously over time and that the assumptions of the legal system about the analytical details of property have also varied enormously. Does property include notions that we might describe as human rights, or individual liberty, as it probably did for Locke ${ }^{139}$ Is property the sole, absolute, and des-

139. My colleague Laura Underkuffler has been particularly insightful in showing how Locke, or for that matter Madison, used "property" in ways that are unfamiliar to modern eyes. Laura Underkuffler, On Property: An Essay, 100 YALE L.J. 127, 132-139 (1990). 
potic dominion that Blackstone wrote about (even though that did not match the reality in his own legal system) $?^{140}$ Are property rights the impermeable wall conjured up by the majority in the Leroy Fibre case, inside which we can do what we will without having to think about the possible conduct of others? $?^{141}$ Is property the bundle of rights that first year law students learn about-more accurately a grab bag of rights, powers, privileges and immunities held together by nothing stronger than nominalism? (We choose to call these things "property," and so they are.)

Each of these conceptions of property is linked in a complicated way to the structure of belief in the larger society and in the legal system from which the property right came. Some of these conceptions are Sunday suits, smart clothing for external consumption, while others are working clothes, the day-to-day approximations used by legal practitioners to solve the problems before them. Our conceptions of property and sovereignty overlap, as the legal realists famously taught us, and the ideas of property taught in a law school classroom are markedly different from the same concept in ordinary language. We do not generally, however, throw up our hands and conclude that the whole concept should be jettisoned.

And what is true for property is true for the public domain. Just as there are many "properties," so too there are many "public domains." To the simple vision of property rights as consisting only of the state of absolute, perfect dominion can be counterposed the simple vision of the public domain as that which exists only where total freedom reigns. Here the "public domain" consists only of complete works that are completely free: free for appropriation, transfer, redistribution, copying, performance, and even rebundling into a new creation, itself covered by intellectual property. ${ }^{142}$ To the "bundle of rights" conception of property, on the other hand, can be counterposed the "bundle of privileges" vision of the public domain, where we assume, for example, that fair use over a copyrighted work is part of the public domain. And to the predictive, legal realist vision of property, "predictions of what the courts will protect in fact," to paraphrase Holmes, ${ }^{143}$ can be counterposed a predictive, critical conception of the public domain, "predictions of what the public can do freely and nothing more pretentious," to paraphrase Benkler. ${ }^{144}$ Lessig's vision of the commons even includes works for which one has to pay, so long as the legal interest is protected merely by a liability rule and the payment is non-discriminatory..$^{145}$

140. 2 WiLliam BLACKSTONE, COMMENTARIES *233.

141. Leroy Fibre Co. v. Chicago Milwaukee \& St. Paul Ry., 232 U.S. 340, 350 (1914).

142. It is no surprise to find this vision of the public domain flourishing at the times and in the places where the concept of property is hailed as being absolute-even if that is far from the actual truth.

143. See Oliver Wendell Holmes, Jr., The Path of the Law, 10 HARV. L. REV. 457, 461 (1897)

144. Benkler, Free as the Air, supra note 25, at 361.

145. It is not exactly clear how Lessig uses the term "liability rule." He uses free software as an example, but under the classic definition, software under the GPL is actually protected by a property rule backed by injunctive remedies. Under a liability rule, you could incorporate free software into a 
Each of these definitions is driven by an explicit or implicit goal. It may be that the public domain consists of those aspects of works which must remain outside of property if copyright's misleading presumptions about creation are to be squared with reality. It may be that the commons is constructed around the twin notions of preventing monopoly control over network protocols in order to preserve innovation, while still allowing for the type of collective management that will avoid a tragedy of the commons. We have not one public domain, not one theory of the public domain, but many. My own point of view is that this is all to the good, though a little clarity is certainly in order. But not everyone agrees.

\section{$\mathrm{X}$}

\section{CONCLUSION: REIFYING THE NEGATIVE?}

What is gained by reifying the negative and imaging a "theory" of the public domain? Edward Samuels. ${ }^{146}$

The process I have described was a gradual one. From having been the invisible Other, the unquestioned margin of intellectual property, the public domain began to attract increasing attention. (Some of it, I must admit, from me, though I have wisely omitted that work from the history in this essay, out of self-preservation if nothing else. $)^{147}$ Soon, this body of work began to receive

proprietary, closed-source, program (itself not subject to the GPL) provided you paid the appropriate level of damages, normally set at "actual harm." This is not the interpretation of the GPL, or the Copyright Act, that the Free Software Foundation supports, and I would have to agree with them. Leaving aside the question of whether or not a commons that includes content protected by liability rules includes free software, is this a useful definition of the commons? The non-discriminatory liability rule does deal with certain problems of open access to networks, protocols, or choke points for innovation. Under a liability rule regime, payment would be disaggregated from control. The Internet Service Provider would, on payment of a fee, get access to the cable company's network to provide competition with the cable company itself. The researchers would be entitled to access the stem cell lines, on payment of a flat statutory access fee to the patent-holder. But some of the types of distributed innovation described later will flourish only under a system where material is available free-meaning at zero cost. The Wind Done Gone might get published under a liability rule regime; Margaret Mitchell's estate could not say "No." They could merely demand a fee, and the potential profits might more than justify the payment. But a system which required pervasive paying of license fees (the Copyright Clearance Center generalized to all forms of data) would surely fail to live up to the appellation of a "commons." It would deter both collective creation by the poor, and complicated, multi-source, incremental innovation even by relatively wealthy institutions. Personally, I would reserve the label "commons" for something closer to Benkler's definition of the public domain-material that an individual is legally privileged to use, absent a showing of individualized facts to the contrary. Nevertheless, Lessig has an important point. The successful commons will often have some form of governance, and liability rules have extraordinary advantages, mitigating one of the largest potential dangers of the intellectual property system. I am probably reading too much into all of this because Lessig's remarkable new book avoids the liability rule definition altogether, simply saying that resources can be "free even though a price must be paid (a park is 'free' in the sense that I mean even if an access fee is required-so long as the access fee is neutrally and consistently applied)." LESSIG, supra note 74 at 20.

146. Edward Samuels, The Public Domain in Copyright Law, 41 J. COPYRIGHT SOC'Y U.S.A. 137, 150 (1993).

147. See Boyle, Shamans, supra note 32; Boyle, Cruel, supra note 46; James Boyle, The First Amendment and Cyberspace: The Clinton Years, 63 LAW \& CONTEMP. PROBS. 337 (Winter/Spring 2000); Boyle, Foucault, supra note 121; James Boyle, Intellectual Property Online, A Young Person's Guide, 10 HARV. J. L. \& TECH. 47 (1997); Boyle, Missing the Point, supra note 69; James Boyle, A 
the ultimate intellectual compliment—thoughtful skepticism from others about whether there was any there, there:

After reviewing the various proposed arguments supporting a general theory of the public domain, by Patterson and Lindberg or by other authors, it would appear that there simply is no such general theory. Instead, there are several discrete contexts in which arguments about the public domain are encountered, each context raising different considerations that may have little or nothing to do with each other, and that cumulatively constitute what remains after one examines all possible sources of legal protection for works of authorship .... What is gained by reifying the negative, and imagining a "theory" of the public domain? If one wants to encourage a presumption against new forms or areas of protection, then one can do so without having to invoke a magical "public domain." There are dozens of battlegrounds between those who want to expand intellectual property protection and those who want to limit it or narrow it in any given context. The arguments in each context should be kept separate, since they raise different policy issues. Nevertheless, the individual issues sometimes tend to be elusive, and one's attitude toward them tends to be flavored as often as not by one's general attitude toward copyright law. If those who find themselves continually on the side arguing for a limitation of protection need a rallying cry, perhaps it can be "the public domain." The invocation may seem to add a moral overtone to the argument, to counterbalance the morally charged principles invoked time and again by the protectionists. In the final analysis, however, "such vague rhetoric does little more than adorn the stage on which actual choices must be played out."148

What is gained by reifying the negative? Professor Samuels' question is a good one. He supplies part of the answer with his thought that perhaps the language of the public domain will be used to counter the language of sacred property. This is, indeed, an important point-language matters, and not just as rhetoric. Even if the limits of my language are not the limits of my world, ${ }^{149}$ the limits of my language certainly influence my world in a deeper way than as "vague rhetoric" adorning a stage, "on which actual choices must be played out."

The analogy I have tried to develop in my writing is that of the environmental movement. ${ }^{150}$ Why talk of "an environment" or "environmental harm?" Why not simply list the pros and cons of each particular piece of development, type of technology, aspect of land use? In each case, there will be issues to be thought about: clean water, beautiful vistas, biodiversity, raised sea levels, the morals of species preservation, skin cancers from thinned ozone layers, carbon sequestration, responsibilities to future generations, and so on. It is not clear that there is any Ariadne's thread that links these issues together. What's more, it is fairly clear that there is no coherent or consistent definition of "nature" or

Politics of Intellectual Property: Environmentalism for the Net?, 47 DUKE L.J. 87 (1997) [hereinafter Boyle, Politics]; Boyle, Theory, supra note 77.

148. Samuels, supra note 146.

149. Ludwig WitTGenstein, Tractatus Logicus Philosophicus $\$ 5.6$ ("The limits of my language mean the limits of my world. ... We cannot think what we cannot think; so what we cannot think we cannot say either.") Gibbon made a simpler but related point in describing the role of language in politics: "Augustus was sensible that mankind is governed by names; nor was he deceived in his expectation that the senate and people would submit to slavery, provided they were respectfully assured that they still enjoyed their ancient freedom." THE PoRTABLE GibBon: THE DECline AND FALl of ThE ROMAN EMPIRE 99 (D. Saunders ed., Viking Press 1952) (1782).

150. Boyle, Politics, supra note 147. 
"the environment." 151 There are certainly lots of discrete contexts in which the idea of nature or the environment is raised, and many different arguments for and against a particular type of development or technology. Why not simply deal case-by-case with the harms to this river, that wetland, this species, or that way of life? Why reify these individual loci of potential harm into a single entity called "the environment?" Part of the answer, of course, is rhetorical. The idea of the environment seems to add a moral overtone to the discussion, to counterbalance the arguments about "progress" and "growth" and "modernity." And this is hardly an unimportant function.

But that is not all there is to it. The environmental movement also gained much of its persuasive power by pointing out that there were structural reasons for bad environmental decisions-a legal system based on a particular notion of what "private property" entailed, and a scientific system that treated the world as a simple, linearly-related set of causes and effects. In both of these conceptual systems, the environment actually disappeared; there was no place for it in the analysis. Small surprise, then, that we did not preserve it very well. In other work, I have argued that the same is true about the public domain. ${ }^{152}$ The fundamental tensions in the economic analysis of information issues, the source-blindness of an original author-centered model of property rights, and the political blindness to the importance of the public domain as a whole (not "my lake," but "The Environment") all come together to make the public domain disappear, first in concept and then, increasingly, as a reality. ${ }^{153}$

Of equal importance is the power of a concept like the environment both to clarify and to reshape perceptions of self-interest. When we are talking about the particular costs of this development proposal or that, the duck hunter is less

\section{As I put it in a previous work:}

[S]mall wonder, then, that faith in Nature is hard to reconcile with the rationalist philosophers' critique of the naturalistic fallacy. Environmental ideas of Nature are often based on a skepticism about the power of reason, and a willingness to put faith in spontaneous order precisely because one knows the limits of one's own knowledge about the working of the system. We reify and anthropomorphize Nature in part to express this "faith in the system." But if we would be suspicious of this anthropomorphism when it is applied to "the Market" or to "national tradition," shouldn't we try to apply the same skepticism and feeling for nuance to "Nature"? Which system, which Nature, is being venerated? Are we humans in it? In medicine, does anything organic count as Natural? Do we let aconite and malaria have their way, smiling indulgently? Or is it merely any plant or mineral "traditionally" used as medicine? In environmental terms, is it some imaginary world without the impact of human history, without landscapes transformed, species eradicated, plant varieties cultivated? Is it "Nature as scenery;" the world with the human interventions we like, whether they are English hedgerows, drystane dykes, the bleak beauty of a Scottish moor, deforested before Dr. Johnson passed it by? The trouble with declaring one's reverence for a system, be it a market, a culture or an ecosystem, is that people actually disagree strongly about what the "natural" state of that system is. Then they disagree further about the normative implications of that natural state. Both sets of disagreements could often benefit from some old-fashioned rationalist skepticism. James Boyle, Against Nature, Times LiTERARY SupPlement, July 24, 1998 (reviewing Phil Macnaghten \& John Urry, Contested Natures (1998)), available at http://www.law.duke.edu/boylesite/ tls98nat.htm. What all of this doesn't mean, of course, is that the concept of Nature, or the Environment, is useless.

152. Boyle, Politics, supra note 147.

153. Id. 
likely to make common cause with the bird-watcher in another region, let alone the person worried about genetic drift in salmon populations or the effect of CFCs on the ozone layer. The idea that there is "an environment" allows a coalition to be built around a reframed conception of common interest. In the narrowest sense, that common interest might be the realization, spurred by greater attention to environmental interrelationships, that wetlands are important to both the duck hunter and the bird-watcher, and that they provide all kinds of ecosystem services. Naming encourages study.

In the broader sense, though, it is not merely the word "environment" that catalyses attention. Rather, there were two very important ideas behind the environmental movement. The first was the idea of ecology-the fragile, complex, and unpredictable interconnections between living systems. ${ }^{154}$ The second was the idea of welfare economics - the ways in which markets can fail to make activities internalize their full costs. ${ }^{155}$ The combination of the two ideas yielded a powerful and disturbing conclusion: Markets would routinely fail to make activities internalize their own costs, particularly their environmental costs. This failure would routinely disrupt or destroy fragile ecological systems, with unpredictable, ugly, dangerous, and possibly irreparable consequences.

These two types of analysis pointed to a general interest in environmental protection, and thus helped to build a large constituency which supported governmental efforts to that end. They were coupled with a simple point from public choice theory-public decisions are particularly likely to be bad when concentrated and well-organized groups with stable, substantial, and well-identified interests face off against diffuse groups with high information costs whose interests, while enormous in the aggregate, are individually small. There are lots of people who might be affected by a decision to rely on a particular power source, say, a coal-burning power plant in the Northeast. There are people who see acid rain killing off the fish in their lake, there are others who worry about particulate emissions, and there are those whose houses will be swallowed up by the sea if global warming lives up to its billing. But in the decisions about energy purchase and planning, they are neither as well-informed, nor is it easy for them to be as well-organized, as the company which proposes to run the particular plant. The notion of "an environmental movement" helps to sustain a coalition that people join, give money to, and so forth, even when the particular issue being lobbied over affects them not at all. By coming to be convinced that they should give loyalty to "the protection of the environment" rather than "oppose the stuff that affects me badly," the diffuse group was able to overcome some collective action problems. Specialized organizations fitting particular niches in the movement (Greenpeace, the Audubon Society, the Environmental Defense Fund, the Nature Conservancy) fulfilled a variety of roles and allowed

154. See id.

155. See Peter BoHM, Social EFFICIEnCy: A CONCISE InTroduction to Welfare ECONOMICs (1973); see also Boyle, Politics, supra note 147. 
people to "subcontract" their information-gathering to experts whose norms and pedigree they trusted. ${ }^{156}$

And, what is true for the environment is-to a striking degree, though not completely_true for the public domain and for the commons. The idea of the public domain takes to a higher level of abstraction a set of individual fightsover this chunk of the genome, that aspect of computer programs, this claim about the meaning of parody, or the ownership of facts. Just as the duck hunter finds common cause with the bird-watcher and the salmon geneticist by coming to think about "the environment," so an emergent concept of the public domain could tie together the interests of groups currently engaged in individual struggles with no sense of the larger context. This notion, in turn, allows people to solve collective action problems in a number of different ways, including the creation of specialized organizations whose technical expertise and lobbying proficiency allows the diffuse interests of a wider public to be better articulated. Here, too, we can learn. The public domain should have its Greenpeace, its Environmental Defense Fund, its Nature Conservancy, its Environmentally Concerned Scientists. In fact, organizations paralleling each of these functions are currently being created. ${ }^{157}$

The analogy goes further. Just as "the environment," or "nature," takes on multiple shadings of meaning to respond to different hopes and fearsbiodiversity, the preservation of beauty, a particular relationship between human beings and the planet-so, too, the various images of the public domain and the commons each expresses a specific set of fears about the dangers of property and hopes about the creative process. Frequently, the concept is constructed as an antonym-mirroring the analytic structure of the dominant idea of property to which it is counterposed. Samuels' skepticism is useful here; more clarity about the contents of the public domain and the relationship between the concept of the commons and of the public domain would indeed be useful. The literature on governing the commons promises to be exceptionally useful here, ${ }^{158}$ as does the sadly neglected tradition of Hohfeldian legal analysis. ${ }^{159}$ Each can offer a different kind of clarity. But just as with the environment, with nature, we do not respond to the revelation that these words are used in multiple and overlapping ways with the conclusion that we should

156. Once I decide that the Environmental Defense Fund does good science and good legal research, I rely on their opinion-leveling the playing field a bit between the power company, with its hired scientists and lawyers, and me.

157. See, e.g., Public Knowledge, http://www.publicknowledge.org (last visited Jan. 14, 2003); Electronic Frontier Foundation's Campaign for Audio Visual Free Expression, http://www.eff.org/cafe (last visited Jan. 14, 2003); Creative Commons, http://www.creativecommons.org (last visited Jan. 14, 2003); Duke Law School's Center for the Study of the Public Domain, http://www.law.duke.edu/news/current/20020905pdic.html (last visited Jan. 14, 2003). There are, of course, other efforts along these lines. Honesty requires the confession that I am involved with several of these organizations as progenitor, advisor, or board member, which doubtless prejudices my selection.

158. See supra Parts I-III.

159. See supra Part VII. 
simply abandon them and deal individually with the pluses and minuses of each development proposal, each dam, each CFC emission. The concept of the environment allows, at its best, a kind of generalized reflection on the otherwise unquestionable presuppositions of a particular mode of life, economy, and industrial organization. At their best, the commons and the public domain can do the same in helping us to reimagine creation, innovation, and speech on a global network. And this seems particularly important today.

The poem with which I began this essay told us: "And geese will still a common lack / Till they go and steal it back." I can't match the terseness or the rhyme, but if we assume that the second enclosure movement will have the benign effects claimed for the first, well, we will look like very silly geese indeed. 